For submission to Water Research (Manuscript ID WR34752R2)

\title{
Source identification of nitrous oxide emission pathways from a single-stage nitritation-anammox granular reactor
}

By

\author{
Muhammad Ali ${ }^{\text {a,b }}$, Rathnayake M.L.D. Rathnayake ${ }^{\mathrm{a}, \mathrm{c}}$, Lei Zhang ${ }^{\mathrm{a}}$, Satoshi \\ Ishii $^{\text {a,d }}$, Tomonori Kindaichi ${ }^{\mathrm{e}}$, Hisashi Satoh ${ }^{\mathrm{a}}$, Sakae Toyoda ${ }^{\mathrm{f}}$, Naohiro \\ Yoshida $^{\mathrm{f}}$ and Satoshi Okabe ${ }^{\mathrm{a}, *}$
}

\section{Category: Original reserch paper}

${ }^{a}$ Division of Environmental Engineering, Faculty of Engineering, Hokkaido University, North 13, West-8, Sapporo, Hokkaido 060-8628, Japan. ${ }^{b}$ King Abdullah University of Science and Technology (KAUST), Water Desalination and Reuse Center (WDRC), Biological and Environmental Science \& Engineering (BESE), Thuwal 23955-6900, Saudi Arabia. ${ }^{c}$ Department of Civil Engineering, Faculty of Engineering, University of Peradeniya, Peradeniya, 20400, Sri Lanka. ${ }^{d}$ Department of soil, water and climate, University of Minnesota, 258 Borlaug Hall, 1991 Upper Buford Circle, St. Paul, MN 55108, USA. ${ }^{e}$ Department of Civil and Environmental Engineering, Graduate School of Engineering, Hiroshima University, 1-4-1 Kagamiyama, Higashihiroshima, Hiroshima 739-8527, Japan. ${ }^{f}$ Environmental Science and Technology, Tokyo Institute of Technology, 4259 Nagatsuta, Midori-ku, Yokohama 226-8502, Japan.

*Corresponding author: Satoshi Okabe, North 13, West-8, Sapporo, Hokkaido 0608628, Phone \& Fax: +81-(0)11-706-6266, E-mail: sokabe@eng.hokudai.ac.jp. 


\section{Abstract}

3 Nitrous oxide $\left(\mathrm{N}_{2} \mathrm{O}\right)$ production pathway in a signal-stage nitritation-anammox sequencing

4 batch reactor (SBR) was investigated based on a multilateral approach including real-time $\mathrm{N}_{2} \mathrm{O}$

5 monitoring, $\mathrm{N}_{2} \mathrm{O}$ isotopic composition analysis, and in-situ analyses of spatial distribution of

$6 \quad \mathrm{~N}_{2} \mathrm{O}$ production rate and microbial populations in granular biomass. $\mathrm{N}_{2} \mathrm{O}$ emission rate was high

7 in the initial phase of the operation cycle and gradually decreased with decreasing $\mathrm{NH}_{4}{ }^{+}$

8 concentration. The average emission of $\mathrm{N}_{2} \mathrm{O}$ was $0.98 \pm 0.42 \%$ and $1.35 \pm 0.72 \%$ of the

9 incoming nitrogen load and removed nitrogen, respectively. The $\mathrm{N}_{2} \mathrm{O}$ isotopic composition analysis revealed that $\mathrm{N}_{2} \mathrm{O}$ was produced via $\mathrm{NH}_{2} \mathrm{OH}$ oxidation and $\mathrm{NO}_{2}{ }^{-}$reduction pathways equally, although there is an unknown influence from $\mathrm{N}_{2} \mathrm{O}$ reduction and/or anammox $\mathrm{N}_{2} \mathrm{O}$

12 production. However, the $\mathrm{N}_{2} \mathrm{O}$ isotopomer analysis could not discriminate the relative contribution of nitrifier denitrification and heterotrophic denitrification in the $\mathrm{NO}_{2}^{-}$reduction

14 pathway. Various in-situ techniques (e.g. microsensor measurements and FISH (fluorescent insitu hybridization) analysis) were therefore applied to further identify $\mathrm{N}_{2} \mathrm{O}$ producers. Microsensor measurements revealed that approximately $70 \%$ of $\mathrm{N}_{2} \mathrm{O}$ was produced in the oxic surface zone, where nitrifiers were predominantly localized. Thus, $\mathrm{NH}_{2} \mathrm{OH}$ oxidation and $\mathrm{NO}_{2}$ reduction by nitrifiers (nitrifier-denitrification) could be responsible for the $\mathrm{N}_{2} \mathrm{O}$ production in the oxic zone. The rest of $\mathrm{N}_{2} \mathrm{O}$ (ca. $30 \%$ ) was produced in the anammox bacteria-dominated anoxic zone, probably suggesting that $\mathrm{NO}_{2}{ }^{-}$reduction by coexisting putative heterotrophic denitrifiers and some other unknown pathway(s) including the possibility of anammox process account for the anaerobic $\mathrm{N}_{2} \mathrm{O}$ production. Further study is required to identify the anaerobic $\mathrm{N}_{2} \mathrm{O}$ production pathways. Our multilateral approach can be useful to quantitatively examine the relative contributions of $\mathrm{N}_{2} \mathrm{O}$ production pathways. Good understanding of the key $\mathrm{N}_{2} \mathrm{O}$ production pathways is essential to establish a strategy to mitigate $\mathrm{N}_{2} \mathrm{O}$ emission from biological nitrogen removal processes. 
Nitrous oxide $\left(\mathrm{N}_{2} \mathrm{O}\right)$ emission from wastewaters is a growing concern and accounts for about $6 \%$ of $\mathrm{N}_{2} \mathrm{O}$ global emission from all sources (the sixth largest contributor) (Ciais et al., 2013). During wastewater treatment, $\mathrm{N}_{2} \mathrm{O}$ is mainly released from biological nitrogen removal systems. Large variations in the $\mathrm{N}_{2} \mathrm{O}$ emissions were reported from biological nitrogen removal processes at bench-scale (0-95\% of nitrogen load) and full-scale wastewater treatment plants (0-14.6\% of nitrogen load) (Kampschreur et al., 2009b). Conventionally, nitrification and denitrification (N\&DN) process was employed for nitrogen removal from wastewaters. However, anaerobic ammonium oxidation (anammox) process has potential to transform nitrogen removal from wastewaters. Nitritation and anammox processes have been used as an alternative treatment process for $\mathrm{NH}_{4}{ }^{+}$-rich wastewater streams (such as digester liquor) and considered as more economical and environmental friendly due to lower oxygen requirement, no external carbon source demand and less sludge production (Kuenen, 2008; Mulder et al., 1995; Okabe et al., 2011a). There are presently more than 110 full-scale anammox-based treatment plants worldwide and about $90 \%$ of the plants are being operated as single-stage systems (nitritation and anammox in one reactor) (Ali and Okabe, 2015; Lackner et al., 2014).

Extensive studies were conducted to study $\mathrm{N}_{2} \mathrm{O}$ emission dynamics and patterns from both two-stage and single-stage nitritation-anammox processes (Table 1). There are three scientifically known biological pathways of $\mathrm{N}_{2} \mathrm{O}$ production in wastewater treatment systems:

47 hydroxylamine $\left(\mathrm{NH}_{2} \mathrm{OH}\right)$ oxidation during nitrification $\left(\mathrm{NH}_{4}^{+} \rightarrow \mathrm{NH}_{2} \mathrm{OH} \rightarrow \mathrm{NOH} \rightarrow \mathrm{N}_{2} \mathrm{O}\right)$

48 (Law et al., 2012; Wunderlin et al., 2012) and $\mathrm{NO}_{2}^{-}$reduction by nitrifiers (nitrifier49 denitrification) (Colliver and Stephenson, 2000; Wrage et al., 2001) and by denitrifiers 50 (heterotrophic denitrification) (Lu and Chandran, 2010). Though not conclusive, possibility of 51 low-level $\mathrm{N}_{2} \mathrm{O}$ production by anammox bacteria was also stated previously by some researchers 52 (Harris et al., 2015; Lotti et al., 2014). Although relatively low $\mathrm{N}_{2} \mathrm{O}$ productions (averagely 
$530.27 \%$ of the incoming nitrogen load) were reported for anammox reactors (Desloover et al., 54 2012; Kampschreur et al., 2008; Okabe et al., 2011a), it was confirmed that anammox reaction 55 was not a main source of the $\mathrm{N}_{2} \mathrm{O}$ emission (Okabe et al., 2011a). For two-stage nitritation56 anammox processes, it was reported that $\mathrm{NH}_{2} \mathrm{OH}$ oxidation pathway accounted for 57 approximately $65 \%$ of total $\mathrm{N}_{2} \mathrm{O}$ production from partial nitrification $(\mathrm{PN}$ ) reactor fed with $58 \mathrm{NH}_{4}^{+}$-rich inorganic synthetic wastewater (Rathnayake et al., 2013). The source of $\mathrm{N}_{2} \mathrm{O}$ was 59 different when a PN reactor was fed with $\mathrm{NH}_{4}{ }^{+}$-rich organic synthetic wastewater (Ishii et al., 60 2014). In their study, heterotrophic denitrification was a main source of $\mathrm{N}_{2} \mathrm{O}$ emission from the 61 PN reactor $\left(70-80 \%\right.$ of total $\mathrm{N}_{2} \mathrm{O}$ production). For single-stage nitritation-anammox processes, 62 the information related to $\mathrm{N}_{2} \mathrm{O}$ production pathways is very limited. The major pathways of $\mathrm{N}_{2} \mathrm{O}$ 63 production in a pilot-scale $\mathrm{PN}$-anammox sequencing batch reactor (SBR) were investigated 64 using online isotopic analysis of off-gas $\mathrm{N}_{2} \mathrm{O}$ with quantum cascade laser absorption 65 spectroscopy (QCLAS) (Harris et al., 2015). In this study, $\mathrm{N}_{2} \mathrm{O}$ emissions increased at high DO 66 concentrations and it was concluded that this increase in $\mathrm{N}_{2} \mathrm{O}$ was due to enhanced nitrifier 67 denitrification based on $\mathrm{N}_{2} \mathrm{O}$ isotopic site preference (SP) measurement. However, the SP value was much higher (up to $40 \%$ ) than previously reported in wastewater treatment systems, though 69 higher SP values (up to 40\%) were observed in soil environments (Toyoda et al., 2011b). 70 Therefore, more studies are needed to fully understand $\mathrm{N}_{2} \mathrm{O}$ production pathways in single-stage 71 nitritation-anammox systems.

72 In order to identify the sources of $\mathrm{N}_{2} \mathrm{O}$ production in a single-stage nitritation-anammox 73 process, a lab-scale sequential batch reactor ( $\mathrm{SBR}$ ) was operated and $\mathrm{N}_{2} \mathrm{O}$ production was 74 monitored at a reactor and microbial community (i.e., granule) level. Microbial community 75 structure was analyzed based on 16S rRNA gene sequences using next-generation sequencing 76 (Illumina MiSeq), and then the spatial distribution and abundance of important N-cycle 77 stakeholders, ammonium-oxidizing bacteria (AOB), nitrite-oxidizing bacteria (NOB) and 78 anammox bacteria, in granules were analyzed by fluorescence in-situ hybridization (FISH). The 
microbial community distribution was related to in-situ $\mathrm{N}_{2} \mathrm{O}$ production as measured by

80 microsensors. Furthermore, temporal changes in intermolecular ${ }^{15} \mathrm{~N}$-site preference (SP) of $\mathrm{N}_{2} \mathrm{O}$

81 in off-gas were measured along with temporal changes in $\mathrm{NH}_{4}^{+}, \mathrm{NO}_{2}^{-}, \mathrm{NO}_{3}^{-}, \mathrm{DO}$ and $\mathrm{pH}$ during

82 reactor operational cycles. Finally, all data were integrated to identify the source of produced

$83 \mathrm{~N}_{2} \mathrm{O}$ in the single-stage nitritation-anammox granular reactor.

\section{Materials and methods}

\subsection{Reactor establishment and operation}

A 2-L lab-scale sequential batch reactor (SBR) (height of $1000 \mathrm{~mm}$ and inner diameter of $58 \mathrm{~mm}$ ) was operated continuously at $37^{\circ} \mathrm{C}$ (Fig. 1S). The volumetric exchange ratio was $50 \%$ and the hydraulic retention time was fixed at 0.5 day. The reactor was configured at $6 \mathrm{hr}$ cycle: $5 \mathrm{~min}$ for feeding, $345 \mathrm{~min}$ for aeration, $5 \mathrm{~min}$ for settling and $5 \mathrm{~min}$ was allocated for effluent withdrawal. A programmable relay (ZEN-10C1AR-A-V2, Omron, Japan) was used to control the actuations of the air and water pumps, and regulated the different phases of the operational cycle. Air was supplied at a flow rate of $150 \mathrm{ml} \mathrm{min} \mathrm{m}^{-1}$ by a diaphragm pump (Laboport N86, KNF, Japan). A ceramic air diffuser located at the bottom of the reactor was used for formation of small bubbles. DO and $\mathrm{pH}$ of the reactor was about $1.0 \mathrm{mg} \mathrm{L}^{-1}$ and 7.6, respectively. Reactor was inoculated with nitrifying biomass (3 g-volatile suspended solid

97 (VSS) $\mathrm{L}^{-1}$ taken from a PN reactor (Rathnayake et al., 2013) and anammox biomass (5 g-VSS L-

$98{ }^{1}$ ) taken from an up flow column reactor (Tsushima et al., 2007). The reactor was fed with 99 synthetic wastewater contained; $\mathrm{NH}_{4}{ }^{+}$(about $300 \mathrm{mg}-\mathrm{N} \mathrm{L}^{-1}$ ), $\mathrm{CaCl}_{2} 100 \mathrm{mg} \mathrm{L}^{-1}, \mathrm{MgSO}_{4} 300 \mathrm{mg}$ $\mathrm{L}^{-1}, \mathrm{KH}_{2} \mathrm{PO}_{4} 30 \mathrm{mg} \mathrm{L}^{-1}, \mathrm{KHCO}_{3} 1500 \mathrm{mg} \mathrm{L}^{-1}$ and trace element solutions (van de Graaf et al., 1995). At steady state operation, an average granular size was $2.42 \pm 1.48 \mathrm{~mm}$ (ca. $70 \%$ of

102 granules have diameters between $1.5-3.5 \mathrm{~mm}$ ).

\section{$2.2 \quad$ Nitrous oxide measurement}


Real-time $\mathrm{N}_{2} \mathrm{O}$ concentrations in the off-gas from the reactor were measured with a 105 photo acoustic field gas monitoring devise (1412, INNOVA, Copenhagen, Denmark). In 106 addition, $\mathrm{N}_{2} \mathrm{O}$ concentrations in the representative off-gas samples were measured using a gas 107 chromatography equipped with electron capture detector (GC-2014, Shimadzu, Kyoto, Japan). 108 The effluent water samples were collected and analyzed by $\mathrm{N}_{2} \mathrm{O}$ headspace technique as 109 described previously (Elkins, 1980; Okabe et al., 2011a).

\section{$2.3 \quad$ Next generation sequencing}

16S rRNA gene amplicon deep sequencing was conducted using the MiSeq technology 112 (Illumina, Hayward, CA) to analysis microbial community structure. Genomic DNA was 113 extracted from the nitritation-anammox granules $(\mathrm{n}=3)$ using a PowerSoil DNA Isolation kit 114 (MoBio Technologies, Carlsbad, CA). The partial 16S rRNA gene sequences including the V3 and V4 regions were then amplified using primers Bakt_341F and Bakt_805R (Herlemann et al., 2011) with Illumina overhang adaptor sequences attached to their 50 ends (Table S1)

117 (Rathnayake et al., 2015). Twenty-five cycles of PCR were confirmed to be necessary and sufficient to reach the log-linear phase based on quantitative PCR analysis conducted using a KAPA SYBR Fast qPCR kit (Kapa Biosystems) and the Bakt_341F and Bakt_805R primers. The purified DNA was mixed with Phi X control DNA and employed as a template for pairedend sequencing using the MiSeq Reagent Kit v2 (500 cycles) and a MiSeq sequencer (Illumina). Sequence reads from triplicate samples were analyzed using QIIME 1.8.0 (Caporaso et al., 2010) with the Silva 119 database.

\subsection{Fluorescence in-situ hybridization}

Granular biomass harvested from the reactor was fixed with $4 \%(\mathrm{w} / \mathrm{v})$ paraformaldehyde in phosphate-buffer saline at $4^{\circ} \mathrm{C}$ for $6 \mathrm{hr}$. Thin sections (10 $\mu \mathrm{m}$ in thickness) of biomass were pasted on teflon coated glass slides and hybridization was performed using hybridization probes NSO190, Ntspa662 and AMX 820 to identify AOB, NOB and anammox bacterial population, 
respectively as described previously (Okabe et al., 1999). Another hybridization was performed using AMX 820 and mix of GNSB941 and CFX1223 (Kindaichi et al., 2012) to detect abundance and spatial distribution of anammox and Chloroflexi bacterial cells, respectively. The probes were labelled with Cy3 (or Alexa Fluor 555), Alexa Fluor 488, or Alexa Fluor 647 at the 5 ' end. Hybridized samples were observed with a LSM700 confocal laser-scanning microscope equipped with diode lasers (488, 555, and $639 \mathrm{~nm}$ ) (Carl Zeiss, Oberkochen, Germany).

\subsection{Microelectrode measurement}

The steady state concentration micro-profiles of $\mathrm{NH}_{4}^{+}, \mathrm{NO}_{2}^{-}$, and $\mathrm{NO}_{3}^{-}$were measured using liquid ion exchanger (LIX) type microelectrodes (de Beer et al., 1997). The sizes of $\mathrm{NH}_{4}^{+}$, $\mathrm{pH}$ and $\mathrm{NO}_{3}{ }^{-}$specific microelectrode tips were between $5-10 \mu \mathrm{m}$ and the sizes of $\mathrm{NO}_{2}{ }^{-}$specific microelectrode tips were between $10-15 \mu \mathrm{m}$ in diameter. Micro-profiles of $\mathrm{DO}$ and $\mathrm{N}_{2} \mathrm{O}$ were measured using DO (OX-25, Unisense, Aarhus, Denmark) and $\mathrm{N}_{2} \mathrm{O}\left(\mathrm{N}_{2} \mathrm{O}-25\right.$, Unisense, Aarhus, Denmark) microsensors, respectively. The microelectrodes were prepared, calibrated, and operated as previously described (Okabe et al., 1999; Satoh et al., 2007). Briefly, granular biomass ( $2-3 \mathrm{~mm}$ diameter size) were harvested from the nitritation-anammox reactor, fixed with insect needles in a flow chamber $(2.5 \mathrm{~L})$ and pre-incubated for $3 \mathrm{hr}$ before microelectrode measurements to ensure that steady-state profiles were obtained. Microelectrodes were inserted almost perpendicular to the surface of the biomass. At least three profiles were measured for each chemical species and separate granule was used for each measurement. Measurement step size was $100 \mu \mathrm{m}$; however, smaller step size $(50 \mu \mathrm{m})$ was chosen where fine resolution measurements were desired. Furthermore, net volumetric $\mathrm{N}_{2} \mathrm{O}$ consumption or production rates were estimated from the respective concentration profiles by using the Fick's second law of diffusion (Lorenzen et al., 1998) and Microsoft EXCEL add-ins solver were applied for the calculations as described previously (Ali et al., 2015).

\section{6 $\quad \mathrm{N}_{2} \mathrm{O}$ isotopomer analysis}


The off-gas samples were collected in gas sampling bag (1LA-6SN, Analytic-barrier,

155 Tokyo, Japan) equipped with turning screw open/close valve at 6, 30, 60, 120, 240 and 345 min

156 of cycle operation during aeration phase from three different operation cycles. Later, the gas

157 samples were injected into evacuated glass serum vials $(120 \mathrm{~mL}$, Nichiden-Rika Glass, Tokyo,

158 Japan) sealed with a rubber stopper and aluminum cap. Subsequently, isotopomer ratios $(\delta)$ of

$159 \mathrm{~N}_{2} \mathrm{O}$ in the off-gas samples were measured using gas chromatograph isotope ratio monitoring

160 mass spectrometry (GC-IRMS, MAT252 system, thermos Fisher Scientific K.K., Yokohama,

161 Japan) as described elsewhere (Toyoda et al., 2011b, 2005). Site-specific nitrogen isotope

162 analysis in $\mathrm{N}_{2} \mathrm{O}$ was conducted using ion detectors, which were modified to allow mass analysis

163 of the fragment ions of $\mathrm{N}_{2} \mathrm{O}\left(\mathrm{NO}^{+}\right)$containing $\mathrm{N}$ atoms in the center positions of $\mathrm{N}_{2} \mathrm{O}$ molecules,

164 whereas the bulk nitrogen and oxygen isotope ratio were determined from molecular ions

165 (Toyoda and Yoshida, 1999), detailed calculations were shown in the supplemental information.

166

167

168

169

170

171

172

173

174

175

\section{Results}

\section{$177 \quad 3.1 \quad$ Reactor performance and efficiency}

\subsection{Chemical Analyses}

Influent and effluent samples were collected and concentrations of $\mathrm{NH}_{4}{ }^{+}, \mathrm{NO}_{2}{ }^{-}$and $\mathrm{NO}_{3}{ }^{-}$ were determined using ion chromatographs (IC-2010, TOSOH, Tokyo, Japan) equipped with TSKgel IC-Anion HS or TSKgel IC-Cation columns (TOSOH, Tokyo, Japan) after filtration using $0.45 \mu \mathrm{m}$-pore-size membranes (Okabe et al., 2011b). DO was measured using a DO meter (DO-5Z, KRK, Tokyo, Japan). Biomass concentration was determined as protein concentration using DC Protein Assay Kit (Bio-Rad, Tokyo, Japan) and bovine serum albumin as protein standard as previously described (Ali et al., 2014). Conversion of protein concentration to VSS concentration was performed with conversion coefficient 1.64 (Oshiki et al., 2011). 
After about six-month operation, the stable nitrogen removal rate (NRR) of $0.4-0.6 \mathrm{~kg}$ -

$\mathrm{N} \mathrm{m}^{-3} \mathrm{~d}^{-1}$ was achieved under the nitrogen loading rate (NLR) of $0.5-0.8 \mathrm{~kg}^{-\mathrm{N} \mathrm{m}} \mathrm{m}^{-3} \mathrm{~d}^{-1}$, corresponding to the total nitrogen removal rate of about $80 \%$ (Fig. 1). However, it should be noted that relatively high concentrations (around $65 \mathrm{mg} \mathrm{L}^{-1}$ ) of $\mathrm{NO}_{3}^{-}$, an end-product of anammox process, remained in the effluent, indicating that complete nitrification (oxidation of $\mathrm{NH}_{4}^{+}$to $\mathrm{NO}_{2}^{-}$and further to $\mathrm{NO}_{3}^{-}$) occurred to some extent. In contrast, the effluent $\mathrm{NO}_{2}^{-}$ concentration was almost zero during the operation. The relative nitrite oxidation rate (NOR), ammonium oxidation rate (AOR) and total nitrogen removal rate by anammox bacteria (ANR) were calculated based on nitrogen balance and the stoichiometry of the anammox process (Vázquez-Padín et al., 2009) (Fig. 1C). Detailed calculations of AOR, NOR and ANR were presented in supplemental information. The mean AOR, NOR and ANR were ascertained about $0.31,0.07$ and $0.50 \mathrm{~kg}-\mathrm{N} \mathrm{m} \mathrm{m}^{-3} \mathrm{~d}^{-1}$, respectively, suggesting that NOR accounted for $14 \%$ of the mean ANR. The biomass concentration in the reactor was stable at around $8 \mathrm{~g}$-VSS L ${ }^{-1}$ during the operation.

\subsection{Cyclic emission of $\mathrm{N}_{2} \mathrm{O}$}

Dissolved $\mathrm{N}_{2} \mathrm{O}$ concentrations in the reactor effluent and gaseous $\mathrm{N}_{2} \mathrm{O}$ concentrations in the off-gas were varied from 0.4 to $240 \mathrm{ppm}$ and from 4.4 to $67 \mu \mathrm{M}$, respectively (Fig. S2). The average $\mathrm{N}_{2} \mathrm{O}$ emission was recorded as $0.98 \pm 0.42 \%$ of the incoming nitrogen load $(1.35 \pm$ $0.72 \%$ of the removed nitrogen), which was comparable with the values reported in the previous studies (Table 1). At the beginning of aeration (operation cycle), $\mathrm{N}_{2} \mathrm{O}$ emission rate was very high and then decreased at the end of aeration (Fig. 2). This trend was reproducible (Fig. S3) and consist with the previous studies of lab-scale PN reactors (Kong et al., 2013a; Rathnayake et al., 2013). The average $\mathrm{N}_{2} \mathrm{O}$ emission rate was measured as $0.26 \pm 0.08 \mathrm{mg}-\mathrm{N} \mathrm{L}^{-1} \mathrm{~h}^{-1}$. The dynamics of $\mathrm{N}_{2} \mathrm{O}, \mathrm{DO}, \mathrm{NH}_{4}^{+}, \mathrm{NO}_{2}^{-}$, and $\mathrm{NO}_{3}^{-}$concentrations in one operation cycle were measured three times and the averages were shown in Fig. 2. Only $\mathrm{NH}_{4}^{+}$concentration rapidly 
increased due to the feed of fresh medium and gradually decreased with time. $\mathrm{DO}$ and $\mathrm{pH}$ were in the range of 0.8 to $1.3 \mathrm{mg}-\mathrm{O}_{2} \mathrm{~L}^{-1}$ and 7.5 to 7.9 , respectively.

\subsection{Microbial community structure}

Bacterial community structure and spatial distribution of $\mathrm{AOB}, \mathrm{NOB}$, anammox bacteria and others in the granules were analyzed by the 16S rRNA gene deep sequencing and FISH analysis. A total of 29,900 sequence reads per sample were obtained from triplicate samples. Microbial community structures were very similar among triplicate samples. The Miseq analysis revealed that anammox bacteria belonging to the order Brocadiales were identified as the sole anammox bacteria in the granules $(12.5 \pm 0.6 \%)$. AOB belonging to the order Nitrosomonadales $(5.0 \pm 0.4 \%)$ and NOB belonging to the phylum Nitrospirae $(12.1 \pm 0.3 \%)$ were also detected in the granules (Fig. 3).

The spatial distribution of $\mathrm{AOB}, \mathrm{NOB}$ and anammox bacteria in the nitritation-anammox granular biomass was analyzed in detail by FISH. The NSO190-stained betaproteobacterial AOB were primarily detected in the outermost surface layer of the granules, and Ntspa662stained NOB cells were detected underneath the AOB cells layer (Fig. 4). This AOB and NOB cells layer was rather thin (only about $50-100 \mu \mathrm{m}$ ). Amx820-stained anammox bacteria dominated inside of granules (underneath the $\mathrm{AOB}$ and $\mathrm{NOB}$ cells layer). Clear stratified spatial distribution of aerobic $\mathrm{AOB}$ and $\mathrm{NOB}$ and anammox bacteria was observed.

Deep sequencing of 16S rRNA gene analysis revealed that the most frequently detected sequence was the Phylum Cholorflexi $(33.1 \pm 0.2 \%)$, which has often been observed in anammox reactors fed with synthetic nutrient medium without organic carbon compounds (Kindaichi et al., 2012; Miura et al., 2007). It is speculated that Cholorflexi act as a scavenger of organic matter derived from anammox bacterial cells (Miura and Okabe, 2008). However, FISH analysis revealed that the abundance of GNSB 941 and CFS 1223-stained Cholorflexi was very low as compared to anammox bacteria cells (Fig. 4S), and they were detected only in the 
anammox bacteria dominated zone. This discrepancy is probably due to PCR amplification bias (Ross et al., 2013) and difference in 16S rRNA gene copy numbers; Chloroflexi species contain up to five 16S rRNA genes per genome (Schirrmeister et al., 2012) whereas anammox bacteria (e.g., Ca. Brocadia) has only one 16S rRNA genes per genome (Oshiki et al., 2015).

\subsection{In-situ microbial activity}

The steady-state concentration profiles of $\mathrm{DO}, \mathrm{NH}_{4}^{+}, \mathrm{NO}_{2}^{-}$, and $\mathrm{NO}_{3}^{-}$in the granular biomass harvested from a single-stage nitritation-anammox reactor were measured under the condition representing the end of operation cycle (i.e., $\mathrm{NH}_{4}^{+}$concentration $<50 \mathrm{mg} \mathrm{L}^{-1}$ ) (Fig. 5). DO was consumed rapidly to below $0.1 \mathrm{mg} \mathrm{L}^{-1}$ at ca. $100 \mu \mathrm{m}$ from the surface of the granule (Fig. 5A). The net volumetric $\mathrm{O}_{2}$ consumption rate was observed down to $250 \mu \mathrm{m}$ depth where simultaneous consumptions of $\mathrm{NH}_{4}{ }^{+}$and $\mathrm{NO}_{2}{ }^{-}$and production of $\mathrm{NO}_{3}{ }^{-}$were observed. No net $\mathrm{NO}_{2}{ }^{-}$production was observed in the oxic and anoxic zones, indicating that $\mathrm{NO}_{2}{ }^{-}$consumption by NOB and anammox bacteria was faster than generation by AOB in the granule. Anammox activity (i.e., nitrogen removal performance) was limited by $\mathrm{NO}_{2}{ }^{-}$availability; because $\mathrm{NH}_{4}{ }^{+}$ was still plenty inside granules but no anammox reaction occurred. The ratios of consumed $\mathrm{NO}_{2}^{-} /$consumed $\mathrm{NH}_{4}{ }^{+}$and produced $\mathrm{NO}_{3}^{-} /$consumed $\mathrm{NH}_{4}{ }^{+}$were 1.21 and 0.34 in the oxic zone $(0-250 \mu \mathrm{m})$ and 0.95 and 0.29 in the anoxic zone $(250-500 \mu \mathrm{m})$, respectively (Table S2). This indicated the simultaneous occurrence of (partial) nitrification and anammox (Fig. 5C). Under low $\mathrm{NH}_{4}^{+}$condition $\left(<50 \mathrm{mg} \mathrm{L}^{-1}\right)$, in-situ $\mathrm{N}_{2} \mathrm{O}$ production was low, whereas high $\mathrm{N}_{2} \mathrm{O}$ productions were observed under high $\mathrm{NH}_{4}{ }^{+}$condition $\left(150 \mathrm{mg} \mathrm{L}^{-1}\right)$ (Fig. 6A). This observation was in line with the time-course change in $\mathrm{N}_{2} \mathrm{O}$ concentration (Fig. 2). The net volumetric $\mathrm{N}_{2} \mathrm{O}$ production rates calculated from the average concentration profiles revealed that approximately $70 \%$ of total $\mathrm{N}_{2} \mathrm{O}$ was produced in the oxic zone (Fig. 6B and 6C). These results suggest that nitrifiers, predominantly present in the outer layer of granules, were mainly responsible for $\mathrm{N}_{2} \mathrm{O}$ production in the oxic zone. Heterotrophic bacteria could be partly responsible for the $\mathrm{N}_{2} \mathrm{O}$ production at the oxic-anoxic interface of the granules (below $100 \mu \mathrm{m}$ ) where anammox 
bacteria were predominantly present. It should be noted that $\mathrm{N}_{2} \mathrm{O}$ production was very dynamic and highly influenced by many operating parameters such as $\mathrm{pH}, \mathrm{DO}, \mathrm{NH}_{4}{ }^{+}$and $\mathrm{NO}_{2}^{-}$ concentrations (Domingo-Félez et al., 2014; Joss et al., 2011; Rathnayake et al., 2015). This is probably the reason that $\mathrm{N}_{2} \mathrm{O}$ microprofiles have relatively large standard deviations.

\section{5 $\quad \mathrm{N}_{2} \mathrm{O}$ isotopomer analysis}

The $\delta^{15} \mathrm{~N}^{\text {bulk }}, \delta^{18} \mathrm{O}$, and SP values were measured for $\mathrm{N}_{2} \mathrm{O}$ molecules collected from the off-gas samples at different stages of the operation cycle (Fig. 7A). Off-gas sample was also collected at $345 \mathrm{~min}$, however, $\mathrm{N}_{2} \mathrm{O}$ isotopic composition could not be measured due to very low $\mathrm{N}_{2} \mathrm{O}$ concentration. The bulk isotopic composition $\left(\delta^{15} \mathrm{~N}^{\text {bulk }}\right)$ refers to the average value of $\delta^{15} \mathrm{~N}^{\alpha}$ and $\delta^{15} \mathrm{~N}^{\beta}$ estimated from equation 1 and 2 (shown in supplemental information), respectively. The SP values were relatively constant $(15-19 \%)$ throughout the cycle. Reduction of $\mathrm{N}_{2} \mathrm{O}$ by heterotrophic denitrification increases the SP value of the remaining $\mathrm{N}_{2} \mathrm{O}$, which hinders from partitioning different production pathways. To overcome these difficulties, combination of site preference data with simultaneous measurements of $\delta^{18} \mathrm{O}$ and $\delta^{15} \mathrm{~N}^{\text {bulk }}$ can help to constrain the effect of $\mathrm{N}_{2} \mathrm{O}$ reduction by heterotrophic denitrification (Toyoda et al., 2011b). The shifts in SP due to $\mathrm{N}_{2} \mathrm{O}$ reduction can be qualitatively evaluated based on the relationships between $\delta^{18} \mathrm{O}$ and $\delta^{15} \mathrm{~N}^{\text {bulk }}$, and $\delta^{18} \mathrm{O}$ and $\delta^{15} \mathrm{~N}^{\alpha}$ (Jinuntuya-Nortman et al., 2008; Ostrom et al., 2007). A line with a slope of 2.5 for the plot of $\delta^{18} \mathrm{O}$ versus $\delta^{15} \mathrm{~N}^{\text {bulk }}$ and 1.7 for the plot of $\delta^{18} \mathrm{O}$ versus $\delta^{15} \mathrm{~N}^{\alpha}$ was regarded as an indicative of $\mathrm{N}_{2} \mathrm{O}$ reduction. Based on this, slopes greater than one for both the relationships were suggested as a criterion to identify the influence of $\mathrm{N}_{2} \mathrm{O}$ reduction on SP (Ostrom et al., 2007). However, in our study, the slopes of lines relating $\delta^{18} \mathrm{O}$ and $\delta^{15} \mathrm{~N}^{\text {bulk }}$, and $\delta^{18} \mathrm{O}$ and $\delta^{15} \mathrm{~N}^{\alpha}$ were 0.14 and 0.15 , respectively, suggesting that the influence of $\mathrm{N}_{2} \mathrm{O}$ reduction on SP value was not significant in this study (Fig. S5). Therefore, relative contributions of $\mathrm{NH}_{2} \mathrm{OH}$ oxidation and $\mathrm{NO}_{2}^{-}$reduction (nitrifierdenitrification and/or heterotrophic denitrification) to $\mathrm{N}_{2} \mathrm{O}$ production were calculated as 
279 described in supplemental information. The relative contributions of $\mathrm{NH}_{2} \mathrm{OH}$ oxidation and $280 \mathrm{NO}_{2}^{-}$reduction were calculated to be $52.1 \pm 2.3 \%$ and $47.9 \pm 2.3 \%$, respectively (Fig. $7 \mathbf{B}$ ), 281 suggesting that their contributions were roughly equal.

\section{Discussion}

284 Better understanding of the pathways and influencing factors for formation and emission of $\mathrm{N}_{2} \mathrm{O}$ is essential to propose effective mitigation strategies. $\mathrm{N}_{2} \mathrm{O}$ isotopomer analysis is a powerful tool to distinguish whether $\mathrm{N}_{2} \mathrm{O}$ originates from $\mathrm{NH}_{2} \mathrm{OH}$ oxidation and/or $\mathrm{NO}_{2}^{-}$ reduction (nitrifier denitrification and heterotrophic denitrification). Previously, isotopic composition of $\mathrm{N}_{2} \mathrm{O}$ produced by pure cultures was investigated; the following SP values were reported: 1) $-10.7 \pm 2.9$ to $0.1 \pm 1.7 \%$ for nitrifier-denitrification by AOB; 2$) 30.8 \pm 5.9$ to 36.3 $290 \pm 2.4 \%$ for $\mathrm{NH}_{2} \mathrm{OH}$ oxidation; and 3) -5 to $0 \%$ for $\mathrm{N}_{2} \mathrm{O}$ production by heterotrophic 291 denitrification (Sutka et al., 2006; Toyoda et al., 2011b).

292 In addition, many field studies were conducted for measurement of isotopic composition of $\mathrm{N}_{2} \mathrm{O}$ (Koba et al., 2012; Yamagishi et al., 2007) including a municipal wastewater treatment plant (Toyoda et al., 2011a). For example, $\mathrm{NH}_{2} \mathrm{OH}$ oxidation pathway accounted for $65 \%$ of the total $\mathrm{N}_{2} \mathrm{O}$ production from a PN reactor fed with synthetic inorganic wastewater (Rathnayake et al., 2013). In contrast, heterotrophic denitrification contributed $70-80 \%$ in production of $\mathrm{N}_{2} \mathrm{O}$ from a PN reactor fed with synthetic wastewater containing organic carbon (Ishii et al., 2014). Later, this technique was applied to a pilot-scale nitritation-anammox reactor to optimize the reactor operation (Harris et al., 2015). However, $\mathrm{N}_{2} \mathrm{O}$ production pathway could not be identified due to unexpected high SP values that have not been observed in wastewater treatment processes so far, suggesting as yet unknown $\mathrm{N}_{2} \mathrm{O}$ production pathways including the possibility of anammox process. 
There are several limitations of $\mathrm{N}_{2} \mathrm{O}$ isotopomer analysis. For example, $\mathrm{N}_{2} \mathrm{O}$ reduction increases the SP value; therefore, isotopomer analysis alone may underestimate the contribution of $\mathrm{NO}_{2}^{-}$reduction pathway, when $\mathrm{N}_{2} \mathrm{O}$ reduction is intense (Ostrom et al., 2007). Secondly, it is not possible to distinguish the relative contributions of nitrifier denitrification and heterotrophic denitrification because both pathways occur through $\mathrm{NO}_{2}{ }^{-}$reduction (Toyoda et al., 2011a). The first problem can be solved with simultaneous measurements of $\delta^{18} \mathrm{O}$ and $\delta^{15} \mathrm{~N}^{\text {bulk }}$ as discussed above in section 3.5. In order to overcome the second problem, several techniques (e.g. microsensor measurements, FISH and microbial community analysis) must be combined together to relate the spatial distributions of $\mathrm{N}_{2} \mathrm{O}$ production rate (function) and microbial populations in nitritation-anammox granules.

For microsensor measurements, it should be noted that the microprofiles presented in this study were artificial profiles that were not actually occurring under reactor conditions because, for example, the reactor hydrodynamic was different. In addition, since these were net concentration profiles as a net result of consumption and production, $\mathrm{NO}_{2}^{-}$consumption and production rates could not be precisely determined from these profiles. Second, the spatial resolution of microelectrode measurements is considered to be about 2-3 times of the tip diameters of microelectrodes (i.e., about $30-50 \mu \mathrm{m}$ in this study), a strict comparison with FISH results would have limitations.

Microsensor results revealed that more than $70 \%$ of the total $\mathrm{N}_{2} \mathrm{O}$ production occurred in the outer oxic zone of the granules, where nitrifiers were predominantly present (Fig. 4 and Fig. 5). Whereas, the rest of $\mathrm{N}_{2} \mathrm{O}$ (about $30 \%$ ) was produced in the anoxic zone, where anammox bacteria and putative heterotrophic denitrifiers mainly inhabited, suggesting anammox, heterotrophic denitrification and/or some other unknown pathway(s) contributed to the $\mathrm{N}_{2} \mathrm{O}$ emission in this zone, as previously reported (Harris et al., 2015). Furthermore, the oxic-anoxic interface was vertically moved and variable, which was highly dependent on various operational 
parameters, i.e. bulk DO concentration, microbial activity, spatial distribution of microbes in granules, surface heterogeneity, and granule size (Domingo-Félez et al., 2014; Rathnayake et al., 2015).

In this study, $\mathrm{NH}_{2} \mathrm{OH}$ oxidation and $\mathrm{NO}_{2}^{-}$reduction pathways contributed roughly equal in $\mathrm{N}_{2} \mathrm{O}$ production. This result was in good agreement with the previous observation implying that about $70 \%$ of $\mathrm{N}_{2} \mathrm{O}$ produced in the oxic zone could be attributed to $\mathrm{NH}_{2} \mathrm{OH}$ oxidation and $\mathrm{NO}_{2}{ }^{-}$ reduction by nitrifiers, and the rest of $\mathrm{N}_{2} \mathrm{O}$ produced in the anoxic zone could be mediated by $\mathrm{NO}_{2}^{-}$reduction by heterotrophic denitrifiers. However, some other unknown pathway(s) might be involved in the $\mathrm{N}_{2} \mathrm{O}$ production such as anammox process (Harris et al., 2015; Wunderlin et al., 2013a). Further study is absolutely necessary to validate the possibility.

Under high $\mathrm{NH}_{4}{ }^{+}$concentration, $\mathrm{N}_{2} \mathrm{O}$ production also increased. It was reported that $\mathrm{N}_{2} \mathrm{O}$ production via $\mathrm{NH}_{2} \mathrm{OH}$ pathway was favored at high $\mathrm{NH}_{3}$ and low $\mathrm{NO}_{2}^{-}$concentrations (Wunderlin et al., 2013a). Similar $\mathrm{N}_{2} \mathrm{O}$ emission pattern was reported earlier in a PN reactor, where the contribution of $\mathrm{NH}_{2} \mathrm{OH}$ oxidation pathway was relatively higher at high $\mathrm{NH}_{4}^{+}$ concentration (Rathnayake et al., 2013). Biotic $\mathrm{N}_{2} \mathrm{O}$ production by $\mathrm{NH}_{2} \mathrm{OH}$ oxidation can be minimized by keeping the concentration of $\mathrm{NH}_{4}{ }^{+}$relatively low (e.g. by intermittent dosing of wastewater). On the other hand, $\mathrm{N}_{2} \mathrm{O}$ production by nitrifier-denitrification is particularly promoted under oxygen-limiting and completely anoxic conditions (Kampschreur et al., 2009b).

The single-stage nitritation-anammox reactor was operated under $\mathrm{NO}_{2}^{-}$-limiting condition in this study (Fig. 1). In order to improve the nitrogen removal performance (anammox activity), more $\mathrm{NO}_{2}^{-}$must be supplied to the anammox zone. The controllable variable would be DO concentration, which must be optimized to maximize the $\mathrm{NH}_{4}^{+}$oxidation to $\mathrm{NO}_{2}^{-}$without unwanted $\mathrm{NO}_{2}^{-}$oxidation to $\mathrm{NO}_{3}{ }^{-}$by $\mathrm{NOB}$ and inhibition of anammox activity (Harris et al., 2015; Joss et al., 2011; Wunderlin et al., 2013b). Since ammonium oxidation to nitrite 
(nitritation) is highly dependent on DO concentration (Vázquez-Padín et al., 2010), adequate

353 DO control is essential for the single-stage nitritation-anammox reaction.

354 In this study, DO concentration was maintained at around $1.0 \mathrm{mg}-\mathrm{O}_{2} \mathrm{~L}^{-1}$, resulting in a 355 clear vertical stratification of microbial populations; aerobic AOB were restricted to a thin outer 356 shell (ca. $100 \mu \mathrm{m})$ while anammox bacteria were present in the inner anoxic zone of the 357 granular biomass (Fig. 4). Active nitrogen transformation occurred within outer $500 \mu \mathrm{m}$ (Fig. 5). 358 The thickness of active zone was dependent on the bulk DO and $\mathrm{NO}_{2}{ }^{-}$concentrations (Nielsen et 359 al., 2005). The volumetric conversion rate of ammonium was very high in the outer layer (100 $360 \mu \mathrm{m})$ of the granular biomass to maintain syntrophy with anammox bacteria and to some extend 361 with NOB (Fig. 5C). Nitrate production was observed in the oxic zone $(0-250 \mu \mathrm{m})$ with an 362 average ratio of produced $\mathrm{NO}_{3}^{-}$to consumed $\mathrm{NH}_{4}^{+}$of about 0.11 , indicating occurrence of

\section{Conclusions}


In this study, $\mathrm{N}_{2} \mathrm{O}$ emission dynamics and sources of a lab-scale single-stage nitritationanammox sequencing batch reactor (SBR) were investigated by applying microscale in-situ analyses (microsensor measurements and FISH) and reactor level analyses $\left(\mathrm{N}_{2} \mathrm{O}\right.$ monitoring and isotopomer analysis). The following conclusions are drawn:

- The average $\mathrm{N}_{2} \mathrm{O}$ emission was $1.35 \pm 0.72 \%$ of the removed nitrogen $(0.98 \pm 0.42 \%$ of the incoming nitrogen load)

- $\mathrm{N}_{2} \mathrm{O}$ isotopomer analysis revealed that the contributions of $\mathrm{NH}_{2} \mathrm{OH}$ oxidation and $\mathrm{NO}_{2}{ }^{-}$ reduction pathways to $\mathrm{N}_{2} \mathrm{O}$ production were roughly equal, although there is an unknown influence from $\mathrm{N}_{2} \mathrm{O}$ reduction and/or anammox $\mathrm{N}_{2} \mathrm{O}$ production.

- Microsensor measurements and FISH analysis revealed that about $70 \%$ of $\mathrm{N}_{2} \mathrm{O}$ was produced in the oxic zone where nitrifiers mainly inhabited, and thus probably through $\mathrm{NH}_{2} \mathrm{OH}$ oxidation and autotrophic $\mathrm{NO}_{2}^{-}$reduction pathways. The rest of $\mathrm{N}_{2} \mathrm{O}$ (ca. $30 \%$ ) was produced in the anammox bacteria-dominated anoxic zone, thus possibly mediated by anammox, heterotrophic denitrification and/or other unknown pathway(s). Further study is required to identify the $\mathrm{N}_{2} \mathrm{O}$ emission source in the anoxic zone.

This study provided important information for establishing appropriate strategies to mitigate $\mathrm{N}_{2} \mathrm{O}$ emission from autotrophic biological nitrogen removal systems, which is essential to reduce the carbon footprint of wastewater treatment plants. Identifying $\mathrm{N}_{2} \mathrm{O}$ emission source allow us to achieve specific design and operational conditions of single-stage nitritationanammox systems.

\section{Acknowledgments}

This research was financially supported by Japan Science and Technology Agency (JST) CREST, Nagase Science and Technology Foundation, and Institute for Fermentation, Osaka (IFO), which were granted to S. Okabe. Authors express gratitude to the Gene Science Division, 
401 Natural Science Center for Basic Research and Development, Hiroshima University for their 402 technical support for FISH analysis. Authors are thankful for Yoshitaka Uchida (Assistant 403 Professor, Hokkaido University) for useful discussion and providing technical support for 404 dissolved $\mathrm{N}_{2} \mathrm{O}$ measurements.

405 
407

408

409

410

411

412

413

414

415

416

417

418

419

420

421

422

423

424

425

426

427

428

429

430

431

432

433

434

435

436

437

438

439

440

441

442

443

444

445

446

447

448

449

450
Ali, M., Okabe, S., 2015. Anammox-based technologies for nitrogen removal: Advances in process start-up and remaining issues. Chemosphere 141, 144-153.

Ali, M., Oshiki, M., Okabe, S., 2014. Simple, rapid and effective preservation and reactivation of anaerobic ammonium oxidizing bacterium "Candidatus Brocadia sinica." Water Res 57, 215-222.

Ali, M., Oshiki, M., Rathnayake, L., Ishii, S., Satoh, H., Okabe, S., 2015. Rapid and successful start-up of anammox process by immobilizing the minimal quantity of biomass in PVASA gel beads. Water Res. 79, 147-157.

Caporaso, J.G., Kuczynski, J., Stombaugh, J., Bittinger, K., Bushman, F.D., Costello, E.K., Fierer, N., Peña, A.G., Goodrich, J.K., Gordon, J.I., Huttley, G. a, Kelley, S.T., Knights, D., Koenig, J.E., Ley, R.E., Lozupone, C. a, Mcdonald, D., Muegge, B.D., Pirrung, M., Reeder, J., Sevinsky, J.R., Turnbaugh, P.J., Walters, W. a, Widmann, J., Yatsunenko, T., Zaneveld, J., Knight, R., 2010. correspondence QIIME allows analysis of high- throughput community sequencing data Intensity normalization improves color calling in SOLiD sequencing. Nat. Publ. Gr. 7, 335-336.

Castro-Barros, C.M., Daelman, M.R.., Mampaey, K.E., van Loosdrecht, M.C.., Volcke, E.I.P., 2015. Effect of aeration regime on $\mathrm{N} 2 \mathrm{O}$ emission from partial nitritation-anammox in a full-scale granular sludge reactor. Water Res 68, 793-803.

Ciais, P., Sabine, C., Bala, G., Bopp, L., Brovkin, V., Canadell, J., Chhabra, A., DeFries, R., Galloway, J., Heimann, M., Jones, C., Quéré, C. Le, Myneni, R.B., Piao, S., Thornton, P., 2013. Carbon and Other Biogeochemical Cycles, in: Climate Change 2013 - The Physical Science Basis. pp. 465-570.

Clippeleir, H. De, Vlaeminck, S.E., Mosquera, M., Boeckx, P., Verstraete, W., Boon, N., 2013. One-stage partial nitritation/anammox at $15^{\circ} \mathrm{C}$ on pretreated sewage: feasibility demonstration at lab-scale. Appl Microbiol Biot 97, 10199-10210.

Colliver, B.B., Stephenson, T., 2000. Production of nitrogen oxide and dinitrogen oxide by autotrophic nitrifiers. Biotechnol. Adv. 18, 219-232.

de Beer, D., Stoodley, P., Lewandowski, Z., 1997. Measurement of local diffusion coefficients in biofilms by microinjection and confocal microscopy. Biotechnol. Bioeng. 53, 151-8.

Desloover, J., Clippeleir, D., Boeckx, P., Du, G., Colsen, J., Verstraete, W., Vlaeminck, S.E., 2011. Floc-based sequential partial nitritation and anammox at full scale with contrasting $\mathrm{N}_{2} \mathrm{O}$ emissions. Water Res 45, 2811-2821.

Desloover, J., Vlaeminck, S.E., Clauwaert, P., Verstraete, W., Boon, N., 2012. Strategies to mitigate $\mathrm{N}_{2} \mathrm{O}$ emissions from biological nitrogen removal systems. Curr. Opin. Biotechnol. $23,474-82$.

Domingo-Félez, C., Mutlu, A.G., Jensen, M.M., Smets, B.F., 2014. Aeration Strategies To Mitigate Nitrous Oxide Emissions from Single-Stage Nitritation/Anammox Reactors. Env. Sci Technol 48, 8784-8792.

Elkins, J.W., 1980. Determination of dissolved nitrous oxide in aquatic systems by gas chromatography using electtron-capture detection and multiple phase equilibration. Anal. Chem. 52, 263-267.

Graaff, M.S. De, Zeeman, G., Temmink, H., Loosdrecht, M.C.M. Van, de Graaff, M.S., van Loosdrecht, M.C.M., Buisman, C.J.N., 2010. Long term partial nitritation of anaerobically treated black water and the emission of nitrous oxide. Water Res. 44, 2171-2178. 
Harris, E., Joss, A., Emmenegger, L., Kipf, M., Wolf, B., Mohn, J., Wunderlin, P., 2015. Isotopic evidence for nitrous oxide production pathways in a partial nitritation-anammox reactor. Water Res. 83, 258-270.

Herlemann, D.P., Labrenz, M., Jürgens, K., Bertilsson, S., Waniek, J.J., Andersson, A.F., 2011. Transitions in bacterial communities along the $2000 \mathrm{~km}$ salinity gradient of the Baltic Sea. ISME J. 5, 1571-1579.

Hu, Z., Lotti, T., Kreuk, M. De, Loosdrecht, M. Van, Kruit, J., Mike, S.M., 2013. Nitrogen Removal by a Nitritation-Anammox Bioreactor at Low. Appl Env. Microb 79, 2807-2812.

Ishii, S., Song, Y., Rathnayake, L., Tumendelger, A., Satoh, H., Toyoda, S., Yoshida, N., Okabe, S., 2014. Identification of key nitrous oxide production pathways in aerobic partial nitrifying granules. Env. Microbiol 16, 3168-3180.

Jinuntuya-Nortman, M., Sutka, R.L., Ostrom, P.H., Gandhi, H., Ostrom, N.E., 2008. Isotopologue fractionation during microbial reduction of $\mathrm{N} 2 \mathrm{O}$ within soil mesocosms as a function of water-filled pore space. Soil Biol. Biochem. 40, 2273-2280.

Joss, A., Derlon, N., Cyprien, C., Burger, S., Szivak, I., Traber, J., Siegrist, H., Morgenroth, E., 2011. Combined nitritation-anammox: Advances in understanding process stability. Environ. Sci. Technol. 45, 9735-9742.

Joss, A., Salzgeber, D., Eugster, J., Roger, K.O., Rottermann, K., Burger, S., Fabijan, P., Leumann, S., Mohn, J., Siegrist, H., 2009. Full-Scale Nitrogen Removal from Digester Liquid with Partial Nitritation and Anammox in One SBR. Env. Sci Technol 43, 53015306.

Kampschreur, M.J., Poldermans, R., Kleerebezem, R., Star, W.R.L. Van Der, Haarhuis, R., Abma, W.R., Jetten, M.S.M., Loosdrecht, M.C.M. Van, van der Star, W.R.L., Haarhuis, R., Abma, W.R., Jetten, M.S.M., van Loosdrecht, M.C.M., 2009a. Emission of nitrous oxide and nitric oxide from a full-scale single-stage nitritation-anammox reactor. Water Sci. Technol. 60, 3211-3217.

Kampschreur, M.J., Temmink, H., Kleerebezem, R., Jetten, M.S.M., van Loosdrecht, M.C.M., 2009b. Nitrous oxide emission during wastewater treatment. Water Res. 43, 4093-4103.

Kampschreur, M.J., van der Star, W.R.L., Wielders, H. a, Mulder, J.W., Jetten, M.S.M., van Loosdrecht, M.C.M., 2008. Dynamics of nitric oxide and nitrous oxide emission during full-scale reject water treatment. Water Res. 42, 812-826.

Kindaichi, T., Yuri, S., Ozaki, N., Ohashi, A., 2012. Ecophysiological role and function of uncultured Chloroflexi in an anammox reactor. Water Sci. Technol. 66, 2556-61.

Koba, K., Fang, Y., Mo, J., Zhang, W., Lu, X., Liu, L., Zhang, T., Takebayashi, Y., Toyoda, S., Yoshida, N., Suzuki, K., Yoh, M., Senoo, K., 2012. The $15 \mathrm{~N}$ natural abundance of the N lost from an N-saturated subtropical forest in southern China 117, 1-13.

Kong, Q., Liang, S., Zhang, J., Xie, H., Miao, M., Tian, L., 2013a. N 2 O emission in a partial nitrification system : Dynamic emission characteristics and the ammonium-oxidizing bacteria community. Bioresour. Technol. 127, 400-406.

Kong, Q., Zhang, J., Miao, M., Tian, L., Guo, N., Liang, S., 2013b. Partial nitrification and nitrous oxide emission in an intermittently aerated sequencing batch biofilm reactor. Chem. Eng. J. 217, 435-441.

Kuenen, J.G., 2008. Anammox bacteria: from discovery to application. Nat. Rev. Microbiol. 6, $320-326$.

Lackner, S., Gilbert, E.M., Vlaeminck, S.E., Joss, A., Horn, H., van Loosdrecht, M.C.M., 2014. Full-scale partial nitritation/anammox experiences-an application survey. Water Res. 55, 
292-303.

Law, Y., Lant, P., Yuan, Z., 2011. The effect of $\mathrm{pH}$ on $\mathrm{N} 2 \mathrm{O}$ production under aerobic conditions in a partial nitritation system. Water Res. 45, 5934-5944.

Law, Y., Ye, L., Pan, Y., Yuan, Z., 2012. Nitrous oxide emissions from wastewater treatment processes. Philos. Trans. R. Soc. Lond. B. Biol. Sci. 367, 1265-77.

Lorenzen, J., Larsen, L.H., Kjaer, T., Revsbech, N., 1998. Biosensor Determination of the Microscale Distribution of Nitrate , Nitrate Assimilation, Nitrification, and Denitrification in a Diatom-Inhabited Freshwater Sediment Biosensor Determination of the Microscale Distribution of Nitrate, Nitrate Assimilati. Appl Env. Microb 64, 32643269.

Lotti, T., Kleerebezem, R., Lubello, C., van Loosdrecht, M.C.M., 2014. Physiological and kinetic characterization of a suspended cell anammox culture. Water Res. 60, 1-14.

Lu, H., Chandran, K., 2010. Factors promoting emissions of nitrous oxide and nitric oxide from denitrifying sequencing batch reactors operated with methanol and ethanol as electron donors. Biotechnol. Bioeng. 106, 390-398.

Miura, Y., Okabe, S., 2008. Quantification of cell specific uptake activity of microbial products by uncultured chloroflexi by microautoradiography combined with fluorescence in situ hybridization. Environ. Sci. Technol. 42, 7380-7386.

Miura, Y., Watanabe, Y., Okabe, S., 2007. Significance of Chloroflexi in performance of submerged membrane bioreactors (MBR) treating municipal wastewater. Environ. Sci. Technol. 41, 7787-7794.

Mulder, A., Vandegraaf, A.A., Robertson, L.A., Kuenen, J.G., 1995. Anaerobic Ammonium Oxidation Discovered In A Denitrifying Fluidized-Bed Reactor. FEMS Microbiol Ecol 16, $177-183$.

Nielsen, M., Bollmann, A., Sliekers, O., Jetten, M., Schmid, M., Strous, M., Schmidt, I., Larsen, L.H., Nielsen, L.P., Revsbech, N.P., 2005. Kinetics, diffusional limitation and microscale distribution of chemistry and organisms in a CANON reactor. FEMS Microbiol Ecol 51, 247-56.

Okabe, S., Oshiki, M., Takahashi, Y., Satoh, H., 2011a. N2O emission from a partial nitrification-anammox process and identification of a key biological process of $\mathrm{N} 2 \mathrm{O}$ emission from anammox granules. Water Res 45, 6461-6470.

Okabe, S., Oshiki, M., Takahashi, Y., Satoh, H., 2011b. Development of long-term stable partial nitrification and subsequent anammox process. Bioresour. Technol. 102, 6801-6807.

Okabe, S., Satoh, H., Watanabe, Y., 1999. In situ analysis of nitrifying biofilms as determined by in situ hybridization and the use of microelectrodes. Appl Env. Microb 65, 3182-3191.

Oshiki, M., Shimokawa, M., Fujii, N., Satoh, H., Okabe, S., 2011. Physiological characteristics of the anaerobic ammonium-oxidizing bacterium "Candidatus Brocadia sinica." Microbiology 157, 1706-1713.

Oshiki, M., Shinyako-Hata, K., Satoh, H., Okabe, S., 2015. Draft Genome Sequence of an Anaerobic Ammonium-Oxidizing Bacterium, "Candidatus Brocadia sinica." Genome Announc. 3, 3-4.

Ostrom, N.E., Piit, A., Sutka, R., Ostrom, P.H., Grandy, a. S., Huizinga, K.M., Robertson, G.P., 2007. Isotopologue effects during N2O reduction in soils and in pure cultures of denitrifiers. J. Geophys. Res. Biogeosciences 112, 1-12.

Rathnayake, R.M.L.D., Oshiki, M., Ishii, S., Segawa, T., Satoh, H., Okabe, S., 2015. Effects of 
dissolved oxygen and $\mathrm{pH}$ on nitrous oxide production rates in autotrophic partial nitrification granules. Bioresour. Technol. 197, 15-22.

Rathnayake, R.M.L.D., Song, Y., Tumendelger, A., Oshiki, M., Ishii, S., Satoh, H., Toyoda, S., Yoshida, N., Okabe, S., 2013. Source identification of nitrous oxide on autotrophic partial nitrification in a granular sludge reactor. Water Res. 47, 7078-7086.

Rodriguez-Caballero, A., Pijuan, M., 2013. N2O and NO emissions from a partial nitrification sequencing batch reactor : Exploring dynamics, sources and minimization mechanisms. Water Res. 47, 3131-3140.

Ross, M.G., Russ, C., Costello, M., Hollinger, A., Lennon, N.J., Hegarty, R., Nusbaum, C., Jaffe, D.B., 2013. Characterizing and measuring bias in sequence data. Genome Biol. 14, R51.

Satoh, H., Miura, Y., Tsushima, I., Okabe, S., 2007. Layered structure of bacterial and archaeal communities and their in situ activities in anaerobic granules. Appl. Environ. Microbiol. $73,7300-7$.

Schirrmeister, B.E., Dalquen, D. a, Anisimova, M., Bagheri, H.C., 2012. Gene copy number variation and its significance in cyanobacterial phylogeny. BMC Microbiol. 12, 177.

Sliekers, a O., Derwort, N., Gomez, J.L.C., Strous, M., Kuenen, J.G., Jetten, M.S.M., 2002. Completely autotrophic nitrogen removal over nitrite in one single reactor. Water Res. 36, 2475-82.

Strous, M., Heijnen, J.J., Kuenen, J.G., Jetten, M.S.M., 1998. The sequencing batch reactor as a powerful tool for the study of slowly growing anaerobic ammonium-oxidizing microorganisms. Appl Microbiol Biot 50, 589-596.

Sutka, R.L., Ostrom, N.E., Ostrom, P.H., Breznak, J. a, Pitt, a J., Li, F., Gandhi, H., 2006. Distinguishing Nitrous Oxide Production from Nitrification and Denitrification on the Basis of Isotopomer Abundances Distinguishing Nitrous Oxide Production from Nitrification and Denitrification on the Basis of Isotopomer Abundances. Appl. Environ. Microbiol. 72, 638-644.

Toyoda, S., Mutobe, H., Yamagishi, H., Yoshida, N., Tanji, Y., 2005. Fractionation of N2O isotopomers during production by denitrifier. Soil Biol. Biochem. 37, 1535-1545.

Toyoda, S., Suzuki, Y., Hattori, S., Yamada, K., Fujii, A., Yoshida, N., Kouno, R., Murayama, K., Shiomi, H., 2011a. Isotopomer Analysis of Production and Consumption Mechanisms of $\mathrm{N}_{2} \mathrm{O}$ and $\mathrm{CH}_{4}$ in an Advanced Wastewater Treatment System. Env. Sci Technol 45, 917-922.

Toyoda, S., Yano, M., Nishimura, S., Akiyama, H., Hayakawa, A., Koba, K., Sudo, S., Yagi, K., Makabe, A., Tobari, Y., Ogawa, N.O., Ohkouchi, N., Yamada, K., Yoshida, N., 2011 b. Characterization and production and consumption processes of $\mathrm{N}_{2} \mathrm{O}$ emitted from temperate agricultural soils determined via isotopomer ratio analysis. Global Biogeochem. Cycles 25, 1-17.

Toyoda, S., Yoshida, N., 1999. Determination of Nitrogen Isotopomers of Nitrous 71, 47114718.

Tsushima, I., Kindaichi, T., Okabe, S., 2007. Quantification of anaerobic ammonium-oxidizing bacteria in enrichment cultures by real-time PCR. Water Res 41, 785-794.

van de Graaf, A.A., Mulder, A., Bruijn, P. De, Jetten, M.S., Robertson, L.A., Kuenen, J.G., 1995. Anaerobic oxidation of ammonium is a biologically mediated process . These include : Anaerobic Oxidation of Ammonium Is a Biologically Mediated Process. Appl Env. Microb 61, 1246-1251. 
601

602

603

604

605

606

607

608

609

610

611

612

613
Vázquez-Padín, J., Fernádez, I., Figueroa, M., Mosquera-Corral, A., Campos, J.-L., Méndez, R., 2009. Applications of Anammox based processes to treat anaerobic digester supernatant at room temperature. Bioresour. Technol. 100, 2988-94.

Vázquez-Padín, J., Mosquera-Corral, A., Campos, J.L., Méndez, R., Revsbech, N.P., 2010. Microbial community distribution and activity dynamics of granular biomass in a CANON reactor. Water Res. 44, 4359-70.

Wrage, N., Velthof, G.L., Van Beusichem, M.L., Oenema, O., 2001. Role of nitrifier denitrification in the production of nitrous oxide. Soil Biol. Biochem. 33, 1723-1732.

Wunderlin, P., Lehmann, M.F., Siegrist, H., Tuzson, B., Joss, A., Emmenegger, L., Mohn, J., 2013a. Isotope signatures of $\mathrm{N}_{2} \mathrm{O}$ in a mixed microbial population system: constraints on $\mathrm{N}_{2} \mathrm{O}$ producing pathways in wastewater treatment. Environ. Sci. Technol. 47, 1339-48.

Wunderlin, P., Siegrist, H., Joss, A., 2013b. Online N2O measurement: The next standard for controlling biological ammonia oxidation? Environ. Sci. Technol. 47, 9567-9568.

Wunderlin, P., Mohn, J., Joss, A., Emmenegger, L., Siegrist, H., 2012. Mechanisms of $\mathrm{N}_{2} \mathrm{O}$ production in biological wastewater treatment under nitrifying and denitrifying conditions. Water Res. 46, 1027-1037.

Xiao, P., Cai, Q., Zhang, D., Lu, P., 2013. Characteristics of nitrogen removal and nitrous oxide production in CANON process.

Yamagishi, H., Westley, M.B., Popp, B.N., Toyoda, S., Yoshida, N., Watanabe, S., Koba, K., Yamanaka, Y., 2007. Role of nitrification and denitrification on the nitrous oxide cycle in the eastern tropical North Pacific and Gulf of California. J. Geophys. Res. 112, 1-15.

Yang, J., Trela, J., Plaza, E., Tjus, K., 2013. N 2 O emissions from a one stage partial nitri fi cation / anammox process in moving bed bio fi $\mathrm{lm}$ reactors. Water Sci. Technol. 68, 144152. 

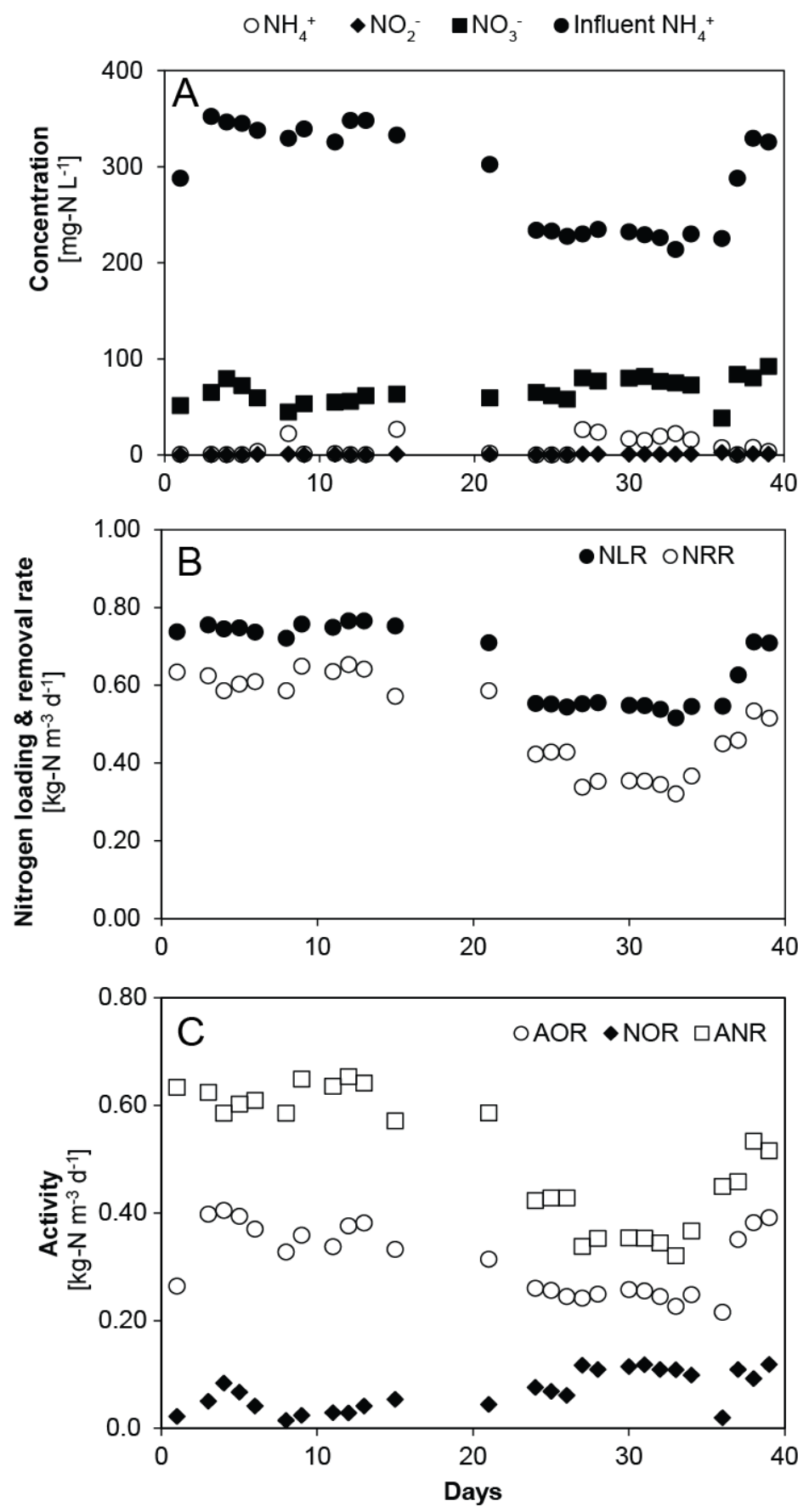

615 Figure 1: Performance of a single-stage nitritation-anammox reactor; A) Influent ammonium 616 (filled circle) concentration and effluent ammonium (empty circle), nitrite (filled diamond) and 617 nitrate (filled square) concentrations measured during the period of study after optimization of 618 the reactor; B) Nitrogen loading (filled circle) and removal (empty circle) rate of the reactor 619 during investigation; C) Activities of AOB (AOR, empty circle), NOB (NOR, filled diamond) 620 and anammox bacteria (ANR, empty square) were calculated based on nitrogen balance and the 621 stoichiometry of the anammox process. 

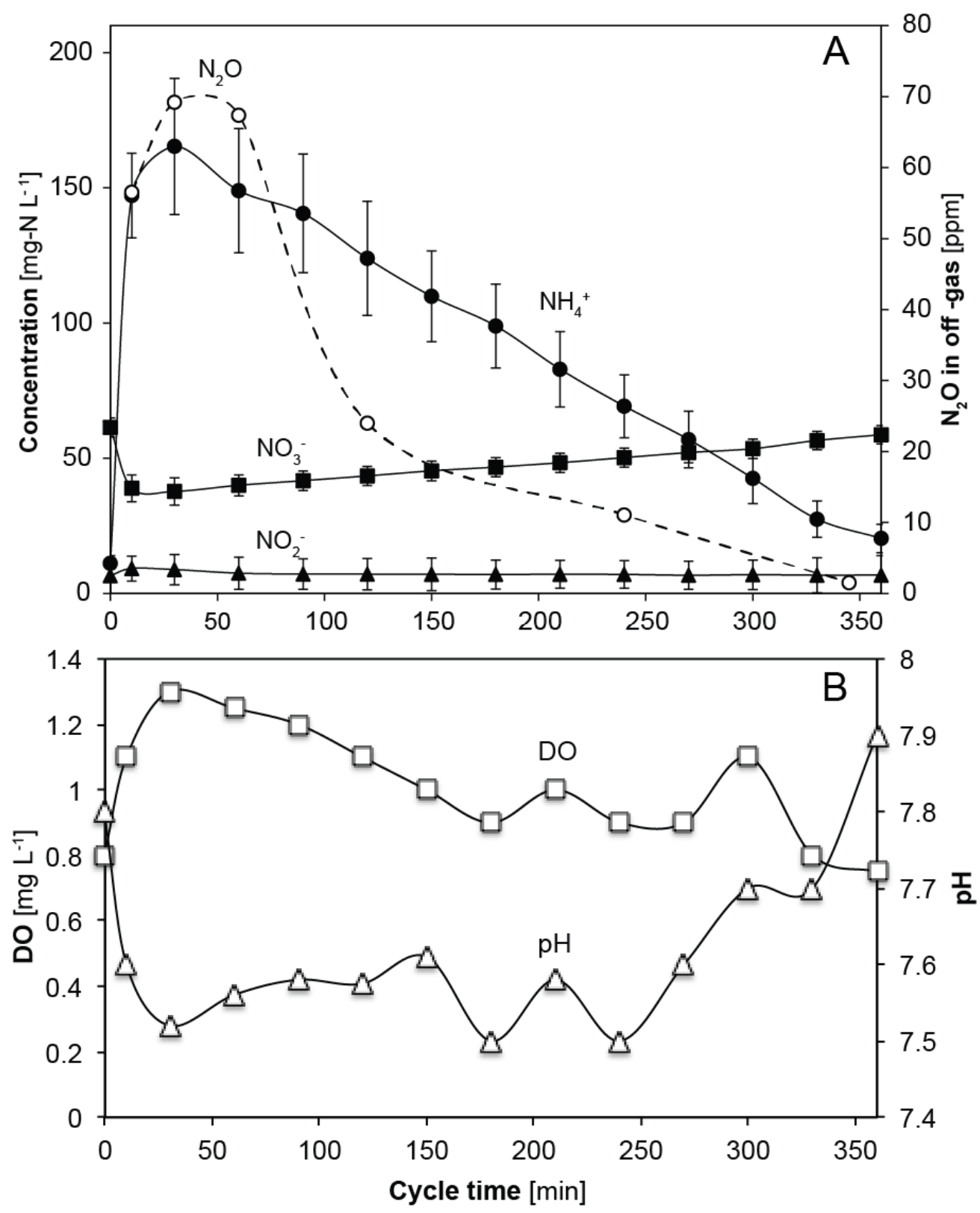

623 Figure 2: A) The concentrations of $\mathrm{NH}_{4}^{+}$(filled circle), $\mathrm{NO}_{2}^{-}$(filled triangle), $\mathrm{NO}_{3}^{-}$(filled 624 square) and $\mathrm{N}_{2} \mathrm{O}$ (open circle) during an operation cycle of the reactor. B) Cyclic pattern of DO 625 and $\mathrm{pH}$ during an operation cycle. Duration of reactor operation cycle was 360 min starting 626 from 0 min: 5, 345, 5 and 5 min were allocated for feeding, aeration, settling and effluent 627 withdrawal. Exchange ratio was 50\%, resulting in hydraulic retention time of 12 hour. Error 628 bars represent the range of standard deviation (SD) among triplicate samples collected from 629 three different operation cycles. 


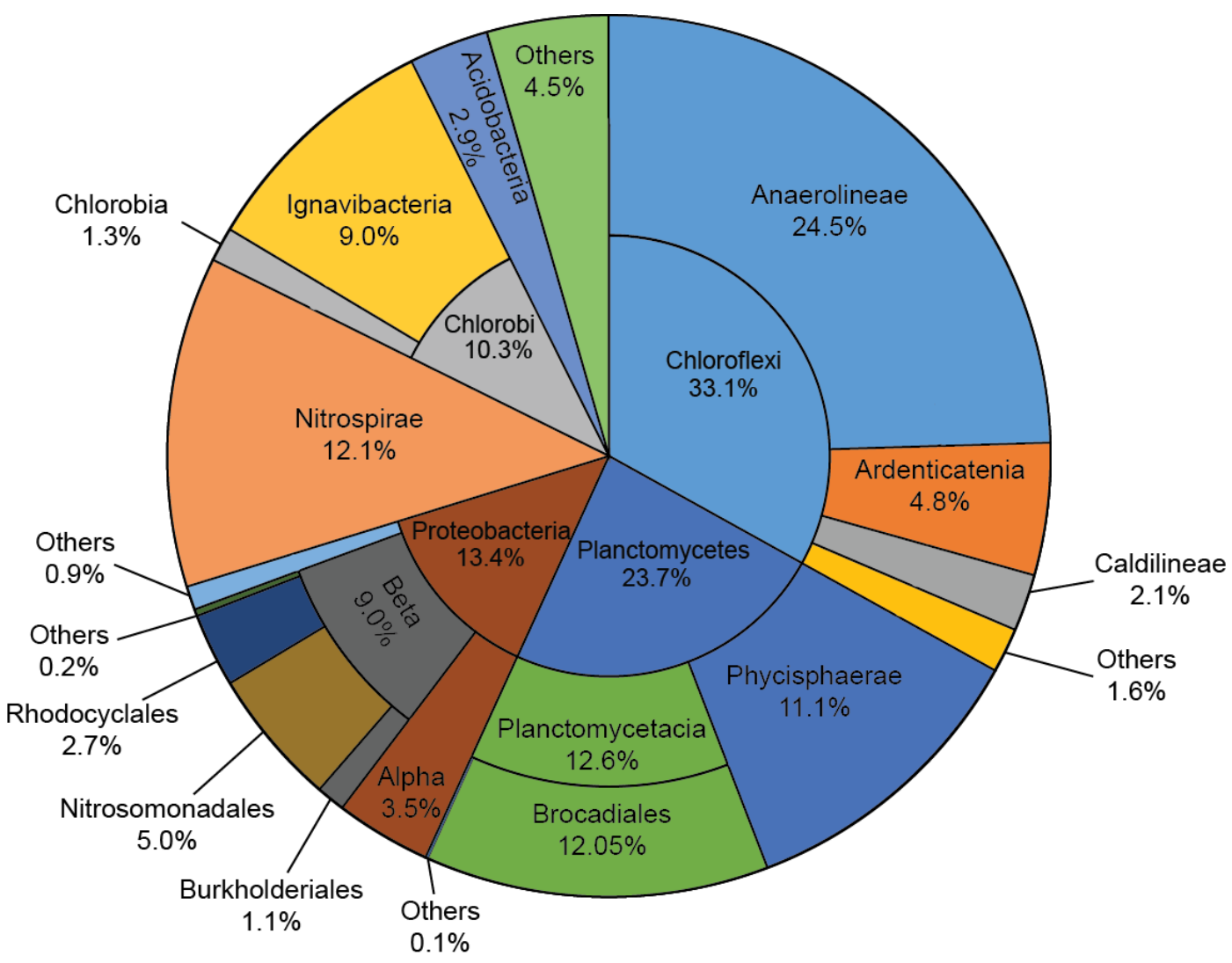

633

634 Figure 3: Microbial community composition of nitritation-anammox granular biomass based on $63516 \mathrm{~S}$ rRNA gene sequences using next-generation sequencing (Illumina MiSeq). The inner, 636 middle and out pie charts show the community composition at the phylum, order and class 637 levels, respectively. Values shown are average of triplicate biomass samples. 

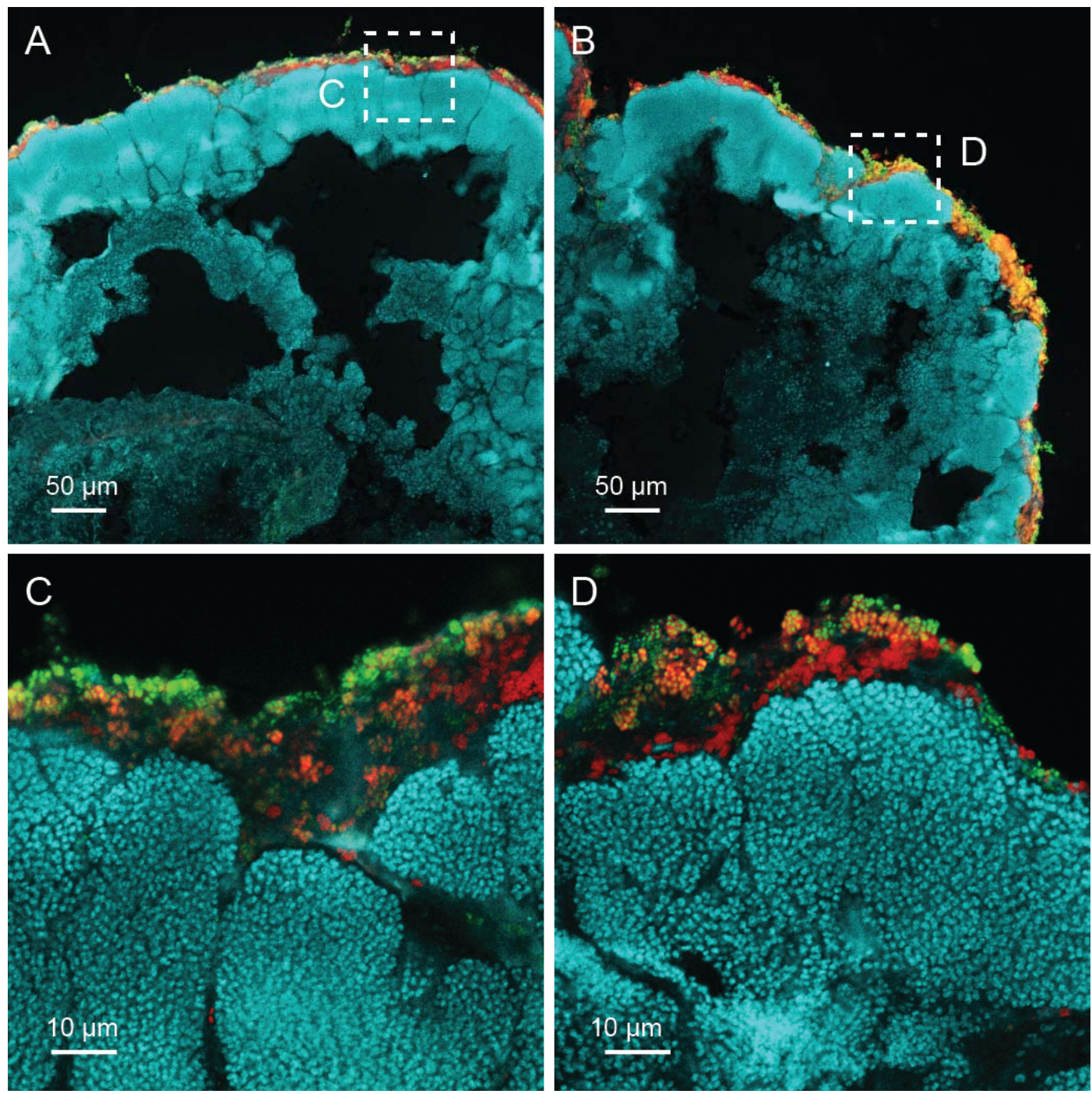

Figure 4: Confocal laser scanning microscope images of thin cross-section of the granular 641 biomass from the nitritation-anammox reactor: These images are showing in-situ spatial 642 organization of ammonia-oxidizing bacteria (AOB, green), nitrite-oxidizing bacteria (NOB, red) 643 and anammox bacteria (blue). Fluorescence in-situ hybridization was performed with Alexa488644 labeled Nso190 probe (green) for AOB and Cy3-labeled Ntspa662 (red) for NOB and 645 Alexa647-labeled Amx820 probe (blue) for anammox bacteria. Dashed lines squares shown in 646 Panel A \& B indicating location of the displayed images in Panel C \& D, respectively. Scale 647 bars represent 50 and $10 \mu \mathrm{m}$ for Panel A \& B and Panel C \& D, respectively. 
A

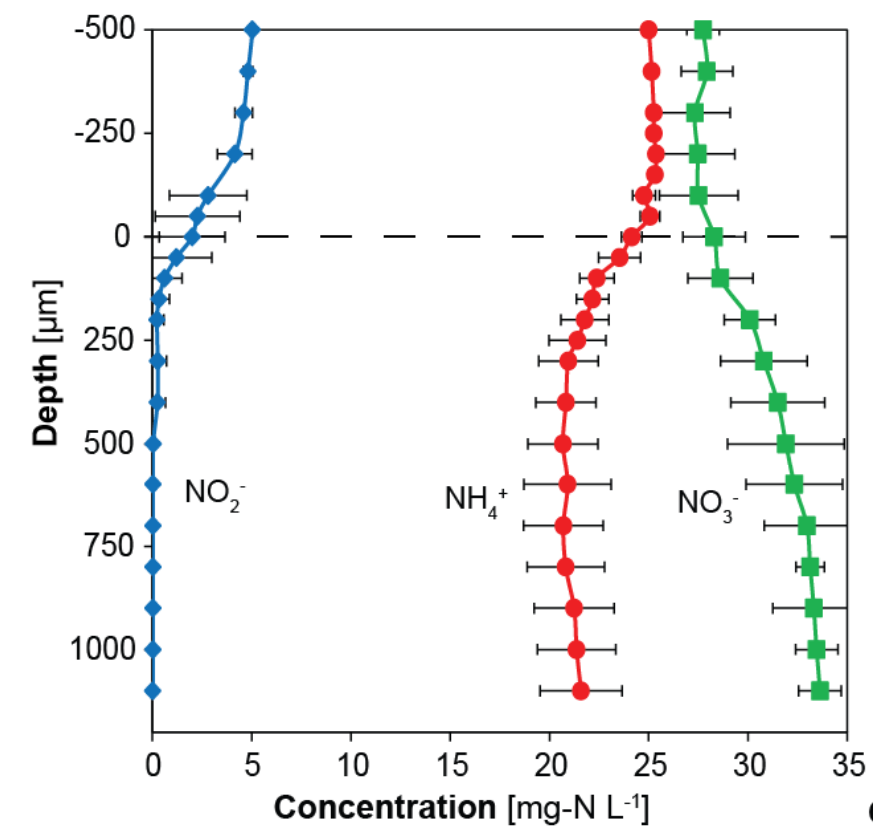

B

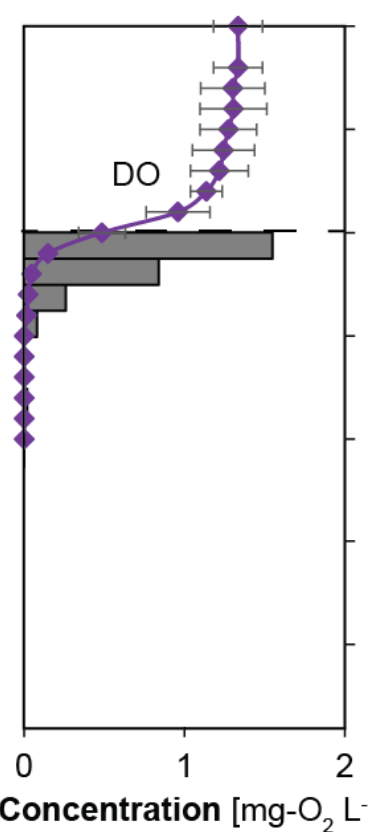

Concentration $\left[\mathrm{mg}-\mathrm{O}_{2} \mathrm{~L}^{-1}\right.$

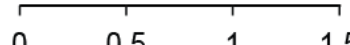

C

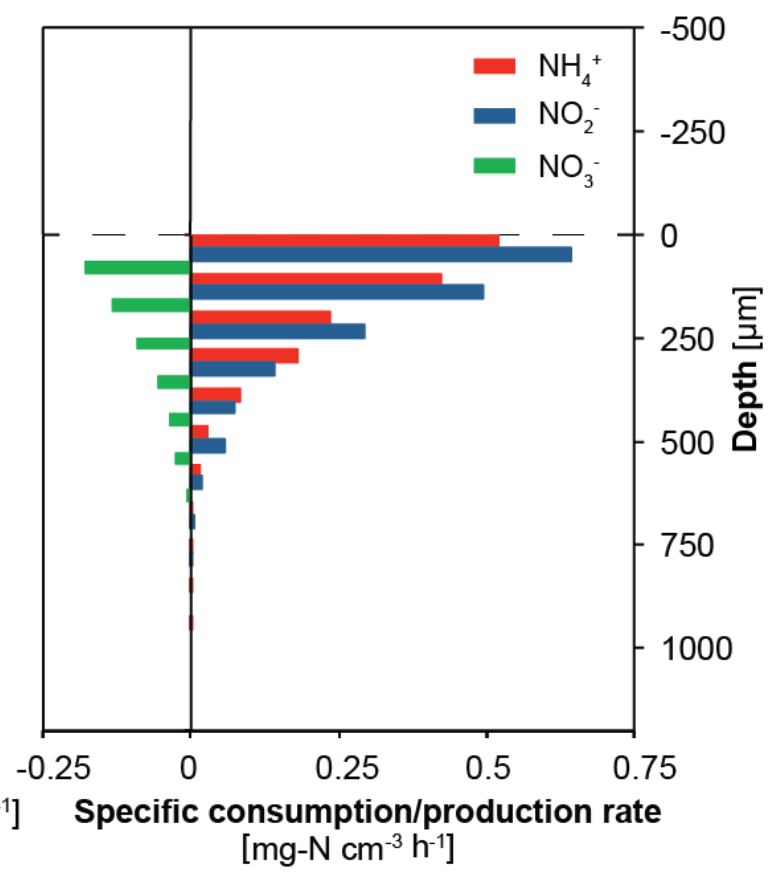

\section{Specific consumption rate}

$$
\left[\mathrm{mg}-\mathrm{O} \mathrm{cm} \mathrm{cm}^{-3} \mathrm{~h}^{-1}\right]
$$

Figure 5: Steady state concentration profiles of $\mathrm{NH}_{4}^{+}$(circle), $\mathrm{NO}_{2}^{-}$(diamond), $\mathrm{NO}_{3}^{-}$nitrate (square) (A) and DO (diamond) (B) in granular biomass of nitritation-anammox reactor. Dashed line represents a liquid-granule interface. Three profiles were measured for each chemical species using three granules. Error bars indicate the range of standard deviations (SD) derived from triplicate measurements. Gary bars are showing spatial distributions of the net volumetric consumption rates of DO, calculated from the average DO concentration profile using Microsoft EXCEL 2013 add-ins solver. (C) Spatial distributions of net volumetric consumption rates of $\mathrm{NH}_{4}^{+}$(red bars) and $\mathrm{NO}_{2}{ }^{-}$(blue bars) and net volumetric production rates $\mathrm{NO}_{3}{ }^{-}$(green bars) were calculated from the corresponding average concentration profiles using Microsoft EXCEL 2013 add-ins solver. 

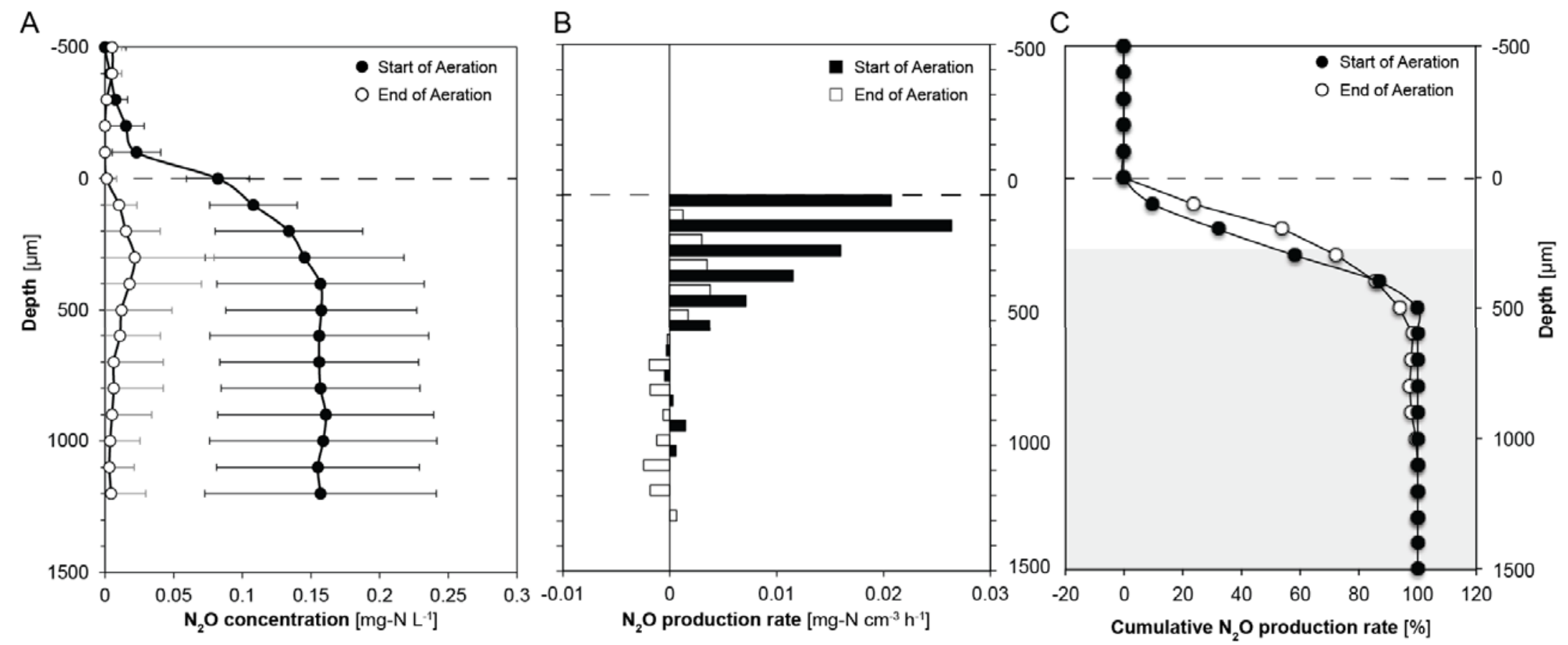

Figure 6: Steady state concentration profiles of $\mathrm{N}_{2} \mathrm{O}$ in the granular biomass harvested from the nitritation-anammox reactor (A). $\mathrm{N}_{2} \mathrm{O}$ concentration profiles were measured under two different operating conditions mimicking the start (filled circle) and end (empty circle) of operation cycle. The start and end of operation cycle refers to high $\mathrm{NH}_{4}{ }^{+}$concentration $\left(150 \mathrm{mg}-\mathrm{N} \mathrm{L}^{-1}\right)$ and low $\mathrm{NH}_{4}^{+}$concentration $\left(25 \mathrm{mg}-\mathrm{N} \mathrm{L}^{-1}\right)$, respectively. Rest of the operating parameters i.e. substrate concentrations, $\mathrm{pH}$, temperature and $\mathrm{DO}$ were kept the same in both incubations. Dashed line represents a liquid-solid interface of granular biomass. Four profiles were measured for each operating condition using different granules. B) Spatial distributions of net volumetric production rates of $\mathrm{N}_{2} \mathrm{O}$ were calculated from the average concentration profiles of $\mathrm{N}_{2} \mathrm{O}$ at the start (filled bars) and end (empty bars) of operation cycle using Microsoft EXCEL 2013 add-ins solver. Positive and negative values indicate the consumption and production rates, respectively. C) Cumulative $\mathrm{N}_{2} \mathrm{O}$ production rate in percentage. Gray shaded area representing as observed anoxic zone in granular biomass. Dashed line represents a liquid-solid interface of granular biomass. 

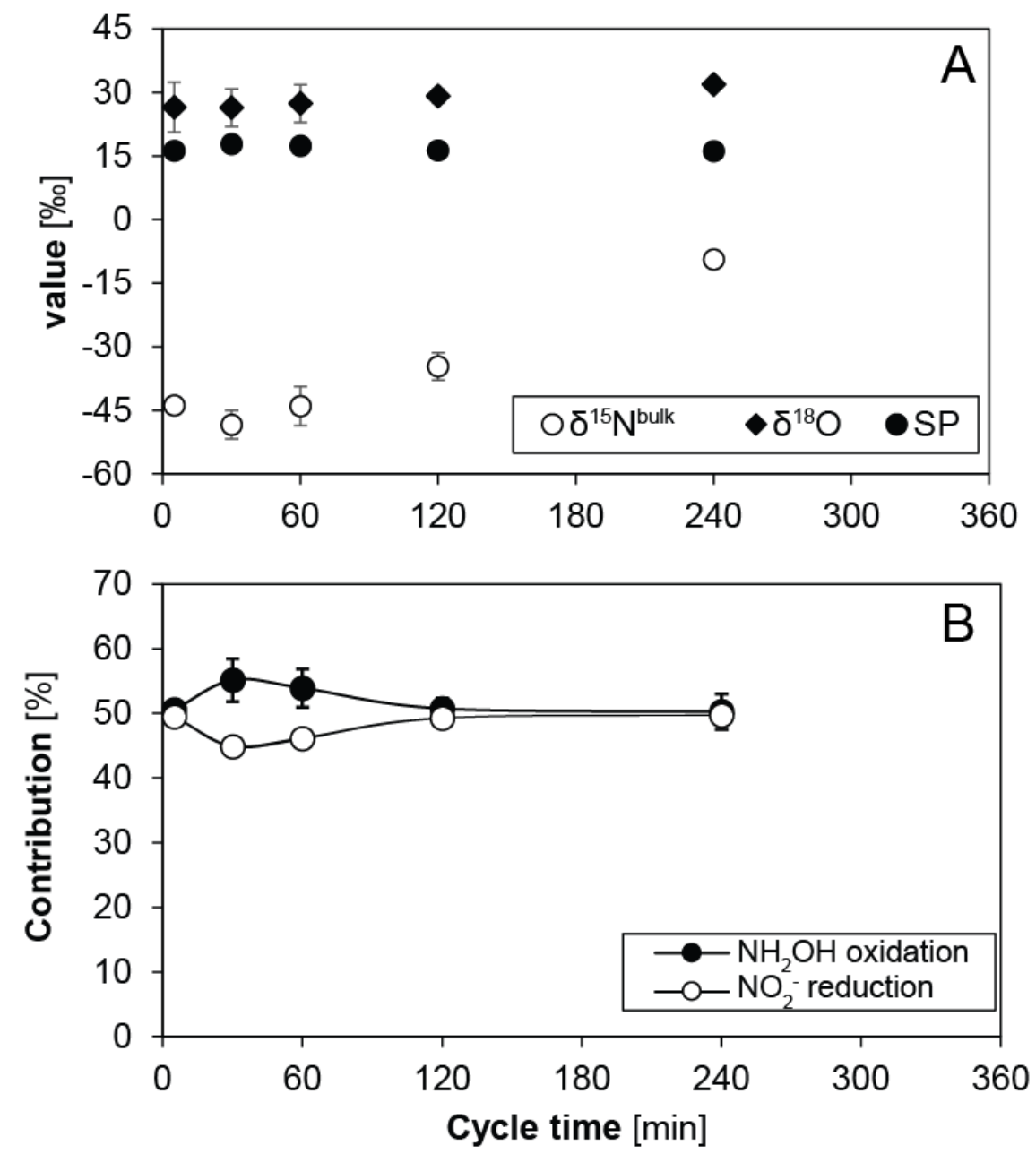

Figure 7: A) $\mathrm{N}_{2} \mathrm{O}$ isotopomer ratios and $\mathrm{SP}$ values in off-gas at each sampling time over one 669 operation cycle. B) Contribution of $\mathrm{NH}_{2} \mathrm{OH}$ oxidation and $\mathrm{NO}_{2}^{-}$reduction pathways to $\mathrm{N}_{2} \mathrm{O}$ 670 emission from the nitritation-anammox reactor. Gas samples were also collected at $345 \mathrm{~min}$, 671 however isotopic composition could not be accurately measured due to very low $\mathrm{N}_{2} \mathrm{O}$ 672 concentration in off-gas. Error bars indicate the range of standard deviation (SD) from triplicate 673 samples collected from three different operating cycles. 
Table 1: Nitrous oxide production rate observed in various studies during biological nitrogen removal process

\begin{tabular}{|c|c|c|c|c|c|c|c|}
\hline \multirow[t]{2}{*}{$\begin{array}{l}\text { S. } \\
\text { No. }\end{array}$} & \multirow[t]{2}{*}{$\begin{array}{l}\text { Reactor } \\
\text { Scale }\end{array}$} & \multirow[t]{2}{*}{ Reactor Type } & $\begin{array}{c}\text { Nitrogen } \\
\text { loading rate } \\
\text { (NLR) } \\
\end{array}$ & $\begin{array}{c}\text { Nitrogen } \\
\text { removal rate } \\
\text { (NRR) } \\
\end{array}$ & $\begin{array}{c}\text { The ratio of } \mathrm{N}_{2} \mathrm{O} \\
\text { production to } \\
\text { NLR }\end{array}$ & $\begin{array}{c}\text { The ratio of } \mathrm{N}_{2} \mathrm{O} \\
\text { production to } \\
\text { NRR }\end{array}$ & \multirow[t]{2}{*}{ Reference } \\
\hline & & & \multicolumn{2}{|c|}{$\left[\mathrm{kg}-\mathrm{N} \mathrm{m}^{-3} \mathrm{~d}^{-1}\right]$} & \multicolumn{2}{|c|}{$[\%]$} & \\
\hline 1 & Full-scale & $\mathrm{PN}$ & 0.65 & 0.34 & 1.7 & 3.3 & $\begin{array}{c}\text { (Kampschreur et al., } \\
\text { 2008) }\end{array}$ \\
\hline 2 & Lab-scale & $\mathrm{PN}$ & 0.52 & 0.31 & $1.9 \pm 0.53$ & 3.22 & (Graaff et al., 2010) \\
\hline 3 & Lab-scale & $\mathrm{PN}$ & 1.25 & 0.63 & $1.50 \pm 0.22$ & 3 & (Kong et al., 2013b) \\
\hline 4 & Lab-scale & $\mathrm{PN}$ & 3 & 1.47 & $0.80 \pm 0.19$ & 1.63 & (Kong et al., 2013a) \\
\hline 5 & Lab-scale & $\mathrm{PN}$ & 2.5 & $1.15 \pm 0.35$ & $4.0 \pm 1.5$ & $9.6 \pm 3.2$ & (Okabe et al., 2011a) \\
\hline 6 & Full-scale & $\mathrm{PN}$ & $0.18-0.22$ & $0.08-0.10$ & $5.1-6.6$ & $11.5-15.5$ & (Desloover et al., 2011) \\
\hline 7 & Pilot-scale & $\mathrm{PN}$ & 0.85 & 0.83 & $6.1 \pm 2.2$ & 6.22 & $\begin{array}{l}\text { (Rodriguez-Caballero and } \\
\text { Pijuan, 2013) }\end{array}$ \\
\hline 8 & Lab-scale & PN & 0.994 & 0.5 & $0.8 \pm 0.4$ & $1.5 \pm 0.8$ & (Rathnayake et al., 2013) \\
\hline 9 & Lab-scale & $\mathrm{PN}$ & 8 & 4.4 & 0.55 & $1.0 \pm 0.1$ & (Law et al., 2011) \\
\hline 10 & Lab-scale & $\begin{array}{l}\text { Aerobic PN } \\
\text { Granules }\end{array}$ & 1.22 & 0.64 & 5.6 & 10.7 & (Ishii et al., 2014) \\
\hline 11 & Full-scale & Anammox & 11.47 & 9.67 & 0.6 & 0.68 & $\begin{array}{c}\text { (Kampschreur et al., } \\
\text { 2008) }\end{array}$ \\
\hline 12 & Lab-scale & Anammox & $11.6 \pm 1.2$ & $7.5 \pm 1.2$ & $0.1 \pm 0.07$ & $0.14 \pm 0.09$ & (Okabe et al., 2011a) \\
\hline 13 & Full-scale & Anammox & 0.27 & 0.26 & 0.1 & 0.1 & (Desloover et al., 2011) \\
\hline 14 & Full-scale & N\&A & 2 & 1.48 & 1.2 & 1.67 & $\begin{array}{l}\text { (Kampschreur et al., } \\
\text { 2009a) }\end{array}$ \\
\hline 15 & Lab-scale & N\&A & 0.1315 & 0.11 & 0.1 & 0.11 & (Sliekers et al., 2002) \\
\hline 16 & Lab-scale & N\&A & $0.30-0.74$ & $0.25-0.61$ & $0.4-2$ & $0.48-2.44$ & (Yang et al., 2013) \\
\hline 17 & Lab-scale & N\&A & 0.025 & 0.021 & 2.45 & 2.4 & (Hu et al., 2013) \\
\hline 18 & Lab-scale & N\&A & 0.69 & 0.48 & $0.28-1.06$ & $0.41-1.53$ & (Xiao et al., 2013) \\
\hline 19 & Full-scale & N\&A & 1.5 & 1.35 & 0.8 & 0.89 & (Joss et al., 2009) \\
\hline
\end{tabular}




\begin{tabular}{|c|c|c|c|c|c|c|c|}
\hline \multirow[t]{2}{*}{$\begin{array}{l}\text { S. } \\
\text { No. }\end{array}$} & \multirow[t]{2}{*}{$\begin{array}{l}\text { Reactor } \\
\text { Scale }\end{array}$} & \multirow[t]{2}{*}{ Reactor Type } & $\begin{array}{c}\text { Nitrogen } \\
\text { loading rate } \\
\text { (NLR) }\end{array}$ & $\begin{array}{c}\text { Nitrogen } \\
\text { removal rate } \\
\text { (NRR) }\end{array}$ & $\begin{array}{c}\text { The ratio of } \mathrm{N}_{2} \mathrm{O} \\
\text { production to } \\
\text { NLR }\end{array}$ & $\begin{array}{c}\text { The ratio of } \mathrm{N}_{2} \mathrm{O} \\
\text { production to } \\
\text { NRR }\end{array}$ & \multirow[t]{2}{*}{ Reference } \\
\hline & & & \multicolumn{2}{|c|}{$\left[\mathrm{kg}-\mathrm{N} \mathrm{m}^{-3} \mathrm{~d}^{-1}\right]$} & \multicolumn{2}{|c|}{$[\%]$} & \\
\hline 21 & Full-scale & $N \& A$ & 1.76 & 1.31 & 2 & 2.69 & $\begin{array}{c}\text { (Castro-Barros et al., } \\
\text { 2015) }\end{array}$ \\
\hline 22 & Lab-scale & $N \& A$ & 0.75 & 0.66 & $1.2-6.0$ & $1.7-7.0$ & $\begin{array}{c}\text { (Domingo-Félez et al., } \\
2014 \text { ) }\end{array}$ \\
\hline
\end{tabular}

675 PN; partial nitrification reactor

676 N\&A; single-stage nitritation-anammox reactor

$677{ }^{a}$ The NRR values reported for $\mathrm{PN}$ reactors are $\mathrm{NH}_{4}{ }^{+}$to $\mathrm{NO}_{2}{ }^{-}$conversion rates for the respective reactor

$678{ }^{\mathrm{b}}$ For all $\mathrm{PN}$ reactors, ratios of $\mathrm{N}_{2} \mathrm{O}$ production rate to conversion rate of $\mathrm{NH}_{4}{ }^{+}$to $\mathrm{NO}_{2}{ }^{-}$are reported here. 


\section{$\mathrm{N}_{2} \mathrm{O}$ production of a single-stage nitritation-anammox reactor}

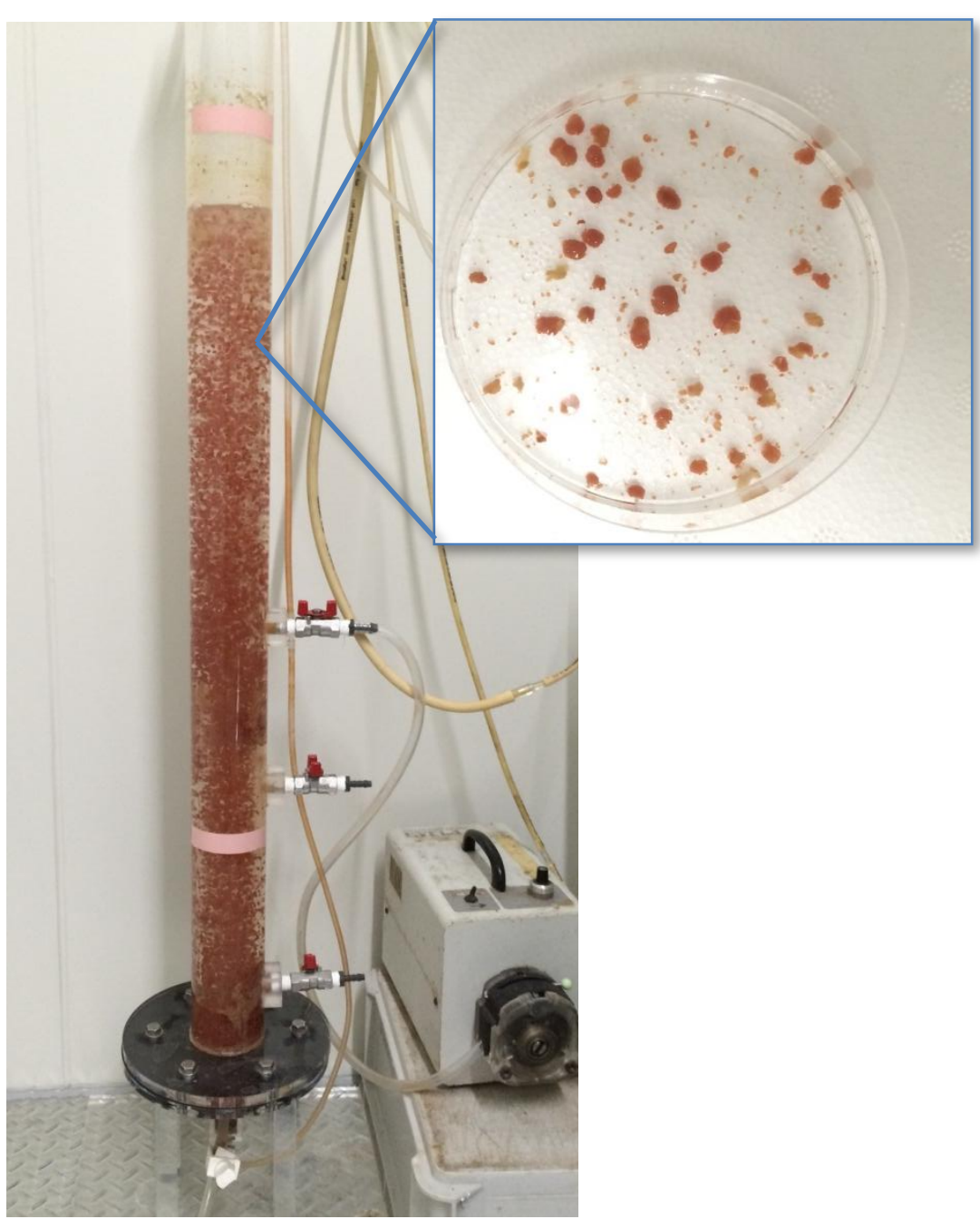

A single-stage nitritationanammox SBR

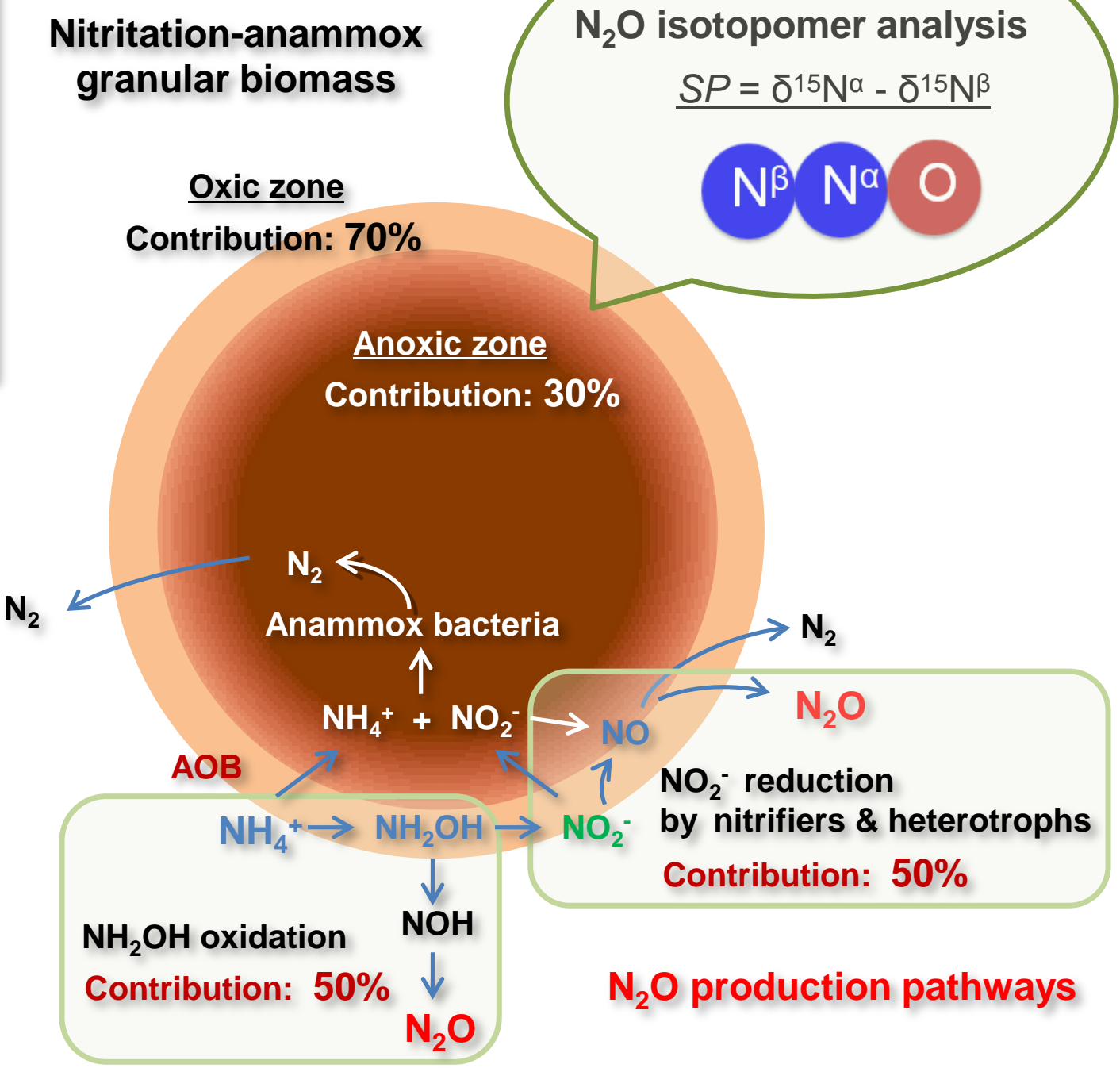

